IZA DP No. 10039

Effects of the Minimum Wage on Infant Health

George Wehby

Dhaval Dave

Robert Kaestner

July 2016 


\title{
Effects of the Minimum Wage on Infant Health
}

\author{
George Wehby \\ University of lowa and NBER
}

Dhaval Dave

Bentley University, NBER and IZA

Robert Kaestner

University of Illinois-Chicago and NBER

\author{
Discussion Paper No. 10039 \\ July 2016
}

IZA
P.O. Box 7240
53072 Bonn
Germany

Phone: +49-228-3894-0

Fax: +49-228-3894-180

E-mail: iza@iza.org

\begin{abstract}
Any opinions expressed here are those of the author(s) and not those of IZA. Research published in this series may include views on policy, but the institute itself takes no institutional policy positions. The IZA research network is committed to the IZA Guiding Principles of Research Integrity.

The Institute for the Study of Labor (IZA) in Bonn is a local and virtual international research center and a place of communication between science, politics and business. IZA is an independent nonprofit organization supported by Deutsche Post Foundation. The center is associated with the University of Bonn and offers a stimulating research environment through its international network, workshops and conferences, data service, project support, research visits and doctoral program. IZA engages in (i) original and internationally competitive research in all fields of labor economics, (ii) development of policy concepts, and (iii) dissemination of research results and concepts to the interested public.
\end{abstract}

IZA Discussion Papers often represent preliminary work and are circulated to encourage discussion. Citation of such a paper should account for its provisional character. A revised version may be available directly from the author. 
IZA Discussion Paper No. 10039

July 2016

\section{ABSTRACT}

\section{Effects of the Minimum Wage on Infant Health*}

The minimum wage has increased in multiple states over the past three decades. Research has focused on effects on labor supply, but very little is known about how the minimum wage affects health, including children's health. We address this knowledge gap and provide an investigation focused on examining the impact of the effective state minimum wage rate on infant health. Using data on the entire universe of births in the US over 25 years, we find that an increase in the minimum wage is associated with an increase in birth weight driven by increased gestational length and fetal growth rate. The effect size is meaningful and plausible. We also find evidence of an increase in prenatal care use and a decline in smoking during pregnancy, which are some channels through which minimum wage can affect infant health. Labor market policies that enhance wages can thus affect wellbeing in broader ways, and such health effects should enter into any cost-benefit calculus of such policies.

JEL Classification: I1, I3, J2, J3

Keywords: minimum wage, health, infant, prenatal care, smoking, income, pregnant women

Corresponding author:

Dhaval Dave

Department of Economics

Bentley University

175 Forest Street

Waltham, MA 02452

USA

E-mail: ddave@bentley.edu

\footnotetext{
${ }^{*}$ The authors are grateful to Wei Lyu and Timothy Roeper for valuable research assistance.
} 


\section{Introduction}

Changing the minimum wage is one of the most common ways that policymakers use to increase income among low-skilled persons. It is also one of the most controversial. Recently, there has been several relatively large increases in minimum wages. Seattle, San Francisco, Los Angeles, New York and Washington DC all have \$15 minimum wage laws on the books. These minimum wage rates are double the current federal level minimum wage, and other states are contemplating similar increases. President Obama passed an executive order raising the minimum wage of federal contractors to $\$ 10.10$. The flurry of recent, legislative activity on the minimum wage and the size of recent minimum wage increases have renewed once again the debate over the value of minimum wage statutes.

Proponents of increasing the minimum wage suggest that it would increase earnings and reduce income inequalities. Opponents, however, argue that an increase in the minimum wage will raise employers' cost of labor, decrease employment and raise prices. The debate is fueled by the fairly mixed evidence on the effects of the minimum wage on employment with some studies finding no significant changes in employment, while others finding a modest decline. Findings related to earnings are more consistent and show that minimum wages raise wages for low-skilled workers.

Notably, potential effects of the minimum wage on non-labor market outcomes such as health are not commonly considered in the debate, which is an oversight, as such effects are important for understanding the full impact of minimum wage policies. Economic theory suggests that an increase in the minimum wage may improve health among workers through an income effect. However, if a higher minimum wage reduces employment for 
some individuals, this can result in an opposite effect for that group. Effects on health may be particularly relevant for infants because of the short, but critical period of gestation that influences infant health; increases in income around the time of pregnancy can affect both maternal health, for example, because of better nutrition and less financial stress, and their babies' health. Evidence from other income-enhancing policies including the earned income tax credit (EITC) indicates a positive effect on infant health among poor mothers. Therefore, understanding how minimum wage changes affect infant health is essential for understanding not only short-term consequences, but also potentially long-run impacts on health given the importance of early life status for long-term wellbeing.

We provide one of the first studies of the effects of minimum wages on infant health. Specifically, we evaluate how state-level minimum wages affect birth weight, gestational age, and fetal growth among births in the US between 1989 and 2012. We employ a difference-in-differences approach to obtain estimates of the effect of minimum wages that are plausibly interpreted as causal. Focusing on a sample of low-educated women, we find that an increase in the minimum wage is associated with a significant increase in birth weight: a $\$ 1$ increase in the minimum wage increases birth weight by about 11 grams, which would imply an 85 grams increase with a \$7.75-dollar increase in the minimum wage from the current federal level of $\$ 7.25$ to $\$ 15$. A $\$ 1$ increase in minimum wage is also associated with a 0.2 percentage point, or $2 \%$, decrease in the probability of low-birth weight. Changes in birth weight and low-birth weight of these magnitudes are clinically important, particularly because they are population averages that mask larger effects for some portion of the sample, and suggest that minimum wages may have important and long-lasting effects on health. 


\section{Relevant Literature}

\section{2.a. Effects of Minimum Wages on Employment and Earnings}

The effects of minimum wages on labor market outcomes has been an actively researched topic. Findings, however, are not uniform. A number of studies find no evidence that minimum wages affect employment (e.g., Addison, Blackburn, \& Cotti, 2012; Dube, Lester, \& Reich, 2010; Card \& Krueger, 1994). In contrast, others find evidence of a decrease in employment (Neumark, Salas, \& Wascher, 2014; Neumark \& Wascher, 1992). The Congressional Budget Office (2014) (https://www.cbo.gov/publication/44995) summarized the literature and concluded that past evidence suggests that an increase in the minimum wage will reduce employment slightly_an increase in federal minimum wage to $\$ 10.10$ from its current level would decrease employment by 0.3 percent.

While the evidence for effects of minimum wages on employment remains mixed, there is consistent evidence suggesting that minimum wages increase earnings for workers. ${ }^{1}$ Positive effects on earnings have been reported in several studies for loweducated and low-income individuals and for both males and females (Belman, Wolfson, \& Nawakitphaitoon, 2015). This evidence is stronger for females for whom the majority of studies find positive effects on earnings (weekly or hourly). Other research suggests that the increase in earnings among the lowest wage workers, who are the ones most affected by increasing minimum wage rates may not necessarily offset the potential decline in work hours or employment status, and that minimum wage increases may have a net negative

\footnotetext{
${ }^{1}$ See: Aaronson, Agarwal, and French (2012); Autor, Katz, and Kearney (2008); Card and DiNardo (2002); David, Manning, and Smith (2016); DiNardo, Fortin, and Lemieux (1996); Lee (1999); Lemieux (2002, 2006); Luttmer (2007); Reich and Hall (2001).
} 
effect on average income for this group (Neumark, Schweitzer, \& Wascher, 2004). The CBO (2014) report, however, concluded that an increase in the minimum wage to $\$ 10.10$ would substantially increase wages for approximately 20 million workers and this increase in income would greatly outweigh the loss in earnings associated with decreased employment. ${ }^{2}$ Overall, the evidence on the labor market effects of the minimum wage suggest that minimum wages will raise income and this greater income may impact health.

\section{2.b. Effects of Minimum Wages on Health}

The literature studying the effects of the minimum wage on health is sparse. Meltzer and Chen (2011) examined the effect of the minimum wage on body mass index (BMI). They reported a negative association; increases in the real minimum wage between 1968 and 2007 were associated with a decrease in BMI. An unpublished paper by Horn, Strain, and Maclean (2016) that used data from the Behavioral Risk Factor Surveillance System (BRFSS) found no evidence of systematic effects on health. For men, they found that minimum wages were associated with an increase in self-reported fair/poor health, but a decline in the number of days with poor mental health. For women, they found a marginally significant decline in number of days in poor mental health and no other significant effects. McCarrier et al. (2011) also used the BRFSS and found that higher minimum wages were associated with lower levels of unmet medical needs. There is also some international evidence suggesting positive health benefits for workers. A recent working paper by Lenhart (2015a) studies the effects of the introduction of the national

\footnotetext{
${ }^{2}$ There is also some evidence that prices will rise, which will reduce real purchasing power: Aaronson (2001); Basker and Khan (2013); Dube, Naidu, and Reich (2007); MacDonald and Aaronson (2006); MaCurdy (2015); Powers (2009).
} 
minimum wage in the UK in 1999 and finds improvements in self-rated health and reported health conditions, with reductions in financial stress and improved financial wellbeing implicated as a potential pathway. Exploiting variation in the minimum wage within 24 OECD countries over time and within US states over time, he also reports improvements in aggregate population health (Lenhart, 2015b).

The closest study to ours is Strully, Rehkopf, and Xuan (2010). This study was mainly focused on the effects of the EITC on birth weight, but it also included the nominal minimum wage in the regression analyses. Strully et al. (2010) found that the minimum wage was positively associated with birth weight and negatively related to maternal, prenatal smoking. A one-dollar increase in the minimum wage was associated with a 3gram increase in birth weight and 7\% decline in the odds of smoking. However, these results were not robust and were specific to only some time periods (pre-1988) and to samples drawn from some states (excluding California, Indiana, Louisiana, Nebraska, New York, Oklahoma, South Dakota, and Washington). In addition, the significance of the estimates is not clear as standard errors ignored likely non-independence of observations within states (Bertrand, Duflo, \& Mullainathan, 2004). The study also had other limitations. $^{3}$

As the brief summary of the previous literature has shown, there is relatively little research on the effects of the minimum wage on health. This is an important gap in knowledge because earnings increases associated with the minimum wage are comparable

\footnotetext{
${ }^{3}$ The regression model included several variables on the causal pathway between minimum wage and infant health such as unemployment rate and poverty indicators.
} 
to those from other policies that have been more thoroughly studied. Indeed, studies on the EITC suggest that modest increases in income among low-income families can improve children's health.

Hoynes, Miller, and Simon (2015) reported that a $\$ 1000$ increase in net after-tax income, from expansions in the federal EITC, was associated with a $2 \%$ to $3 \%$ decline in low birth weight. They also find that this positive income effect from the EITC expansion was associated with an increase in prenatal care use and a decline in maternal smoking, which are potential mechanisms for the increase in birth weight. The EITC has also been shown to be correlated with a decline in maternal smoking (Averett \& Wang, 2013; Cowan \& Tefft, 2012). Strully et al. (2010) found that living in a state that has its own EITC was related to nearly a 15 gram increase in birth weight and 5\% decline in smoking odds using 1980-2002 natality data. The state EITC has also been linked to improved overall child health rating later in childhood including ages 6 to 14 (Baughman \& Duchovny, 2016). Positive effects on maternal health including self-reported health rating as well as biomarkers have also been reported (Evans \& Garthwaite, 2014), providing further evidence for a potential mechanism through maternal health and health behaviors.

To summarize, we extend the literature on the effects of the minimum wage on health. We focus on infant health because of the critical nature of the prenatal period, which is short and easily linked to the potential income effects of the minimum wage. We use data spanning a 25-year period in which there was substantial variation in minimum wages. We examine multiple infant health and maternal behavioral outcomes, consider multiple measures of the minimum wage, and allow for cumulative effects of the minimum 
wage effect. Furthermore, while focusing on low-educated mothers who are most likely to be affected by the minimum wage, we examine several subgroups within this population by age, education, race, and marital status. Even though we find positive effects across all subgroups, we also find some important heterogeneity.

\section{Mechanisms Linking Minimum Wage and Infant Health}

Conceptually, an increase in the minimum wage can improve infant health through a positive income effect on maternal health and health behaviors that can have effects on fetal health. As noted above, the majority of studies examining earnings report an increase in hourly or weekly wages following a rise in the minimum wage, with larger effects among women than men (Belman et al., 2015; Congressional Budget Office, 2014). Greater income from an increase in the minimum wage can improve nutrition. As noted above, there is evidence linking a higher minimum wage to lower BMI, which may also occur through a higher minimum wage raising prices of out-of-home food consumption (Meltzer \& Chen, 2011). More generally, an increase in income may affect consumption of healthy and unhealthy goods such as alcohol and smoking. Greater income may increase medical care such as prenatal care services, particularly among those who are in low-paying jobs, likely to be affected by the minimum wage and likely to be without health insurance. Increased income may increase financial security, which may reduce maternal stress, a factor linked to fetal growth (Camacho, 2008). As noted above, there is also some evidence linking the minimum wage to fewer days in poor mental health among workers (Horn et al., 2016). There may be additional effects stemming from these changes, for example, greater financial security, less stress and improved mental health may reduce health behaviors 
such as smoking that are often used to treat stress (Byrne \& Mazanov, 2016; Saffer \& Dave, 2005).

On the other hand, the positive effects of the minimum wage through increased earnings among workers may be offset by potential declines in employment. Two studies reported employment declines when focusing on very low-educated women (Pinoli, 2010; Sabia, 2008). Given the evidence of an increase in earnings relative to the decline in employment, however, it is reasonable to hypothesize a net positive income effect on infant health among low-income women. Using data from the Current Population Survey (CPS), we provide some evidence of an increase in household income and in annual as well as hourly earnings on average among low-educated women of childbearing age, which is the sample we focus on for examining effects on children's health (see Appendix Table A1).

If the minimum wage affects employment, this may also lead to reallocation of time use due to the easing of time constraints and an increase in non-work/leisure time. Greater availability of time, ceteris paribus, may lead to an increase in time-intensive activities, including certain health-promoting behaviors such as preparing healthy meals at home and exercising or obtaining preventive healthcare.

An increase in the minimum wage may also reduce reliance on welfare programs such as food stamps (SNAP). There is evidence of a decline in enrollment and expenditures on the Supplemental Nutrition Assistance Program (SNAP) with increasing minimum wage rates (Reich \& West, 2015). However, there is no evidence for effects on other welfare program participation such as the Special Supplemental Nutrition Program for Women, Infants, and Children (WIC), Medicaid enrollment, housing assistance programs, and cash 
assistance programs including Aid to Families with Dependent Children (AFDC) and Temporary Aid to Needy Families (TANF) (Sabia \& Nguyen, 2015).

Finally, price effects related to the minimum wage may result in reduced consumption, some of which may have adverse effects on maternal and infant health such as food consumption, grocery shopping and housing improvement. However, evidence suggests very modest increases in prices with the largest effects on restaurants (MaCurdy, 2015).

Overall, the evidence on the effects of the minimum wage on employment, earnings, participation in social welfare programs and prices suggest that the minimum wage will have salutary effects on maternal and infant health. This is because the dominant effect of the minimum wage is to raise incomes of workers. There are small offsetting effects related to employment loss and higher prices, although higher prices may reduce consumption of unhealthy goods as well as healthy products. Thus, we expect that the minimum wage will be positively associated with infant health.

\section{Research Design}

Our empirical analysis is motivated by the mechanisms just described linking the minimum wage to infant health. We estimate a reduced-form model that directly links the state-level minimum wage to infant health outcomes. The research design is a differencein-differences approach focusing on the "intention-to-treat" effect of increasing the minimum wage. For each measure of infant health, we estimate the following regression specification:

$$
H_{i s t}=\alpha_{s}+\theta_{t}+\delta M W_{s t}+X_{i s t} \Gamma+Z_{s t} \Psi+\mu_{i s t}
$$


In equation (1), $\mathrm{H}$ denotes a specific measure of infant health (e.g., birth weight) or maternal behavior (e.g., prenatal care) for a given birth $i$ occurring in state $s$ and year $t$. $M W$ is the minimum wage effective in the given state and pregnancy year. Equation (1) includes year $(\theta)$ and state fixed effects $(\alpha)$. The vector $X$ represents individual characteristics of the mother such as age, education, marital status, and race/ethnicity; and $Z$ represents a vector of time-varying, state-level confounding factors matched to the pregnancy year. These capture concurrent policy shifts affecting low-educated mothers over the sample period, which prior studies have linked to maternal behavioral health and/or infant health, most notably expansions in the state's earned income tax credit, expansions in Medicaid eligibility, welfare reform, and cigarette taxes (Baughman, 2012; Corman et al., 2013; Currie \& Gruber, 1996; Dave et al., 2008; Dave et al., 2010; Evans \& Garthwaite, 2014; Howell, 2001; Hoynes et al., 2015; Kaestner \& Lee, 2005). ${ }^{4}$

In order to control for other time-varying, state-level unobservable variables, we also include the state-year specific mean of the dependent variable for college-educated, married pregnant women between the ages of $25-39$. These women earn wages that make it likely that they would be unaffected by minimum wage policies. Note that this does not amount to using college-educated married pregnant women as a comparison group since we are not constraining the coefficient to be one (as would be the case in a difference-indifference-in-differences context). We include this variable to control for time-varying,

\footnotetext{
${ }^{4}$ Expansions of the federal earned EITC were also underway over this period. Specifically, an EITC expansion that passed in 1993 and became effective in tax year 1995 raised the maximum credit for all qualifying families and further increased the differential in maximum benefits between families with two or more children relative to those with only one child. In 2001, the income level at which the EITC began to phase out for couples was further increased. These federal expansions, along with shifts in the national price level and other trends, are captured by the year $(\theta)$ fixed effects
} 
state-specific changes in the outcomes proportionally affecting low- and higher-educated mothers. However, we can assess whether this proportional effect is one-to-one, thereby assessing whether the higher educated group is a valid control within a difference-indifference-in-differences (DDD) specification. Except for a subset of models for prenatal care and prenatal smoking, we generally reject this restriction, and therefore do not utilize college-educated mothers as a direct comparison group.

The parameter of interest is $\delta$, which captures the reduced-form effect of the increase in the state's effective minimum wage. This effect is identified off the substantial variation in the effective minimum wage within states over this period (see Figure 1). In some analyses, we test for cumulative effects of the minimum wage by using the 2- or 3year average of minimum wages. Higher income, due to an increase in the minimum wage prior to pregnancy may allow families to have more savings and smooth consumption during pregnancy.

We estimate equation (1) for all low-educated women and for several demographic groups defined by age, race and education because there may be heterogeneous responses and because different demographic groups are more or less likely to be affected by the minimum wage. Table 1 provides some evidence as to which demographic groups may be more or less affected by the minimum wage. Table 1 shows the fraction of working females, across subgroups based on education, age, race, and marital status, who are compensated hourly. On average, the vast majority of low-educated (high-school graduate or below) workers earn an hourly wage, and this fraction is relatively similar across less than high school educated workers (82\%) versus high school graduates (79\%). A significantly higher fraction of younger earners are paid hourly (85\% among individuals 18-29 years of age, 
versus $76 \%$ of individuals ages $30-39$ ), as are unmarried earners ( $83 \%$ vs. $77 \%$ ).

Furthermore, about $34 \%$ of low-educated workers who are paid hourly earn at or close to the minimum wage $(<125 \%$ of the minimum wage). This fraction is substantially higher among the lowest-educated (less than high school educated), non-whites, unmarried, and younger earners. Specifically, $42-44 \%$ of hourly-compensated workers who have less than a high school degree or who are between the ages of 18-29 earn close to the minimum wage.

\section{Data}

\section{5.a. Natality Files}

Our data come primarily from information on individual birth records from the Vital Statistics Natality Files. Detailed information on all individual births occurring in the 50 states and DC are submitted by hospitals to state vital registration offices, which is then reported to the National Center for Health Statistics (NCHS). Information on each birth includes date and place of birth along with the demographic characteristics of the mother such as age, race, education, marital status, and parity. We use data for the years 1989 through 2012 that cover pregnancies from 1988 through 2012. We begin our analysis in1989 as earlier years did not contain information on certain prenatal behaviors, and this period also enveloped some of the largest changes in the state minimum wage. Given that shifts in the minimum wage affect more low-educated workers, the primary sample is limited to women with a high-school degree or less between the ages of 18 to 39 (at time of pregnancy). This yields up to 45.8 million births for the main analytical sample.

We measure two categories of infant health: 1) birth weight; and 2) gestation. Birth weight is measured as a continuous outcome (grams) and alternately as an indicator for 
low birth weight (infant was born weighing less than 2,500 grams). Gestational age is measured continuously in weeks, and also as an indicator for whether the infant was born preterm (gestation $<37$ weeks). ${ }^{5}$

In order to assess potential mechanisms linking the minimum wage to infant health, we also study key measures of prenatal inputs available in the birth certificate data. First, we use two measures of prenatal smoking: smoking participation and smoking more than 5 cigarettes daily during pregnancy. ${ }^{6}$ Birth certificates are generally thought to provide a reasonably reliable source of data on prenatal smoking status for large observational studies (Nielsen et al., 2014), although underreporting of smoking status has been suggested for as much as one-fifth of smokers (Tong et al., 2013). While underreporting can inflate our variance estimates, there is no a priori indication that it is systematically correlated with the state's minimum wage legislation in a way that necessarily biases our estimates of the minimum wage effects, conditional on state and time fixed effects and the other controls in our models. We utilize two measures of prenatal care: an indicator for whether there were fewer than five prenatal visits over the pregnancy, and the number of months that prenatal care was delayed since the start of pregnancy. ${ }^{7}$

\footnotetext{
${ }^{5}$ Prior to 2014, gestational age of a newborn was based on the date of the last normal menses (LNM). Beginning in 2014, there has been a transition to a new standard based on the obstetric estimate due to some concerns that the LNM measure may have weaker validity due to issues with imperfect maternal recall and other forms of misinterpretation. Martin, Osterman, Kirmeyer, and Gregory (2015) nevertheless find that the two measures were in agreement for the 2013 birth certificates. The obstetric estimate was within 1 week of the LNM estimate for a total of $83.4 \%$ of records, and within 2 weeks for $91.4 \%$ of all 2013 records.

${ }^{6}$ These outcomes are not reported by some states (for instance, CA, IN, NY, SD, OK) over all or part of our sample period. We exclude births occurring in these states when analyzing these behaviors. Limiting all analyses to those states with consistent information on smoking does not materially alter our results or conclusions.

${ }^{7}$ For brevity, we present main results for these two measures of prenatal care utilization. In the Appendix, we also present results for the number of prenatal care visits. Results are highly similar, in terms of relative magnitudes, significance, and direction of effects, for total visits as well as other
} 


\section{5.b. Minimum Wage}

The effective minimum wage in a given state is the higher of the state's legislated minimum wage or the federal minimum wage. We obtain these data from the US Department of Labor. ${ }^{8}$ Figure 1 shows the considerable variation in the minimum wage across states and over time. Over our sample period (1988-2012), the federal minimum wage increased from $\$ 3.35$ to $\$ 7.25$. Among states, which had set a minimum wage that superseded the federal level, the average minimum wage increased from $\$ 3.74$ to $\$ 7.92$. Currently, there are 29 states plus DC with minimum wage rates set higher than the federal minimum wage of $\$ 7.25$ /hour, compared with 10 states in 1988 . We follow the literature (Card, 1992; Clemens, 2015), and normalize the effective minimum wage by the median wage rate in the state, and refer to this as the "relative minimum wage". The motivation underlying this relative measure is to capture the "bite" of the minimum wage; if the median hourly wage in the state is substantially higher than the minimum wage, then the minimum wage is less binding, and increases in the minimum wage may elicit smaller responses on labor outcomes (Lee, 1999). Therefore, we take the ratio of the nominal minimum wage in the state to the prevailing state-specific median "hourly" wage. The median wage is estimated from annual earnings and work hours from the March CPS. ${ }^{9}$ The

measures of prenatal care access such as first trimester initiation or an indicator for prenatal care adequacy based on the Kotelchuck criteria (Kotelchuck, 1994).

${ }^{8}$ See: https://www.dol.gov/whd/state/stateminwagehis.htm.

${ }^{9}$ We use the March CPS to compute the denominator, which is the state-specific median hourly wage in each year. This is calculated as reported wage and salary income divided by the total number of hours worked in the reference year (product of weeks worked and hours worked in a usual week). We also computed two alternate measures of the median hourly wage from the CPS merged outgoing rotation groups. The first is based on all workers who report on their earnings and hours worked in the past week; this sample includes those who are paid hourly as well as non-hourly. We also computed the median hourly wage for those who report being paid hourly. The correlation across these two measures from the outgoing rotation groups and the measure based on the March CPS is expectedly high, ranging from 0.90 
larger is this ratio, the more binding is the effective minimum wage in the state. ${ }^{10}$ To address any potential endogeneity concerns from the minimum wage concurrently affecting the median wage rate in the state, we use the one-year lag of the median wage. ${ }^{11}$ In alternate specifications, we use the nominal minimum wage and the minimum wage adjusted for inflation using the consumer price index (denoted in constant 2012 dollars). ${ }^{12}$

Using the birth records from 1989-2012, we impute the year of pregnancy inception based on birth year and gestational age to identify pregnancies that were started between 1988 and 2012. We match the average minimum wage to the birth records by state and over the pregnancy period. For women who conceive and give birth in the same year, this is the relative minimum wage in effect during that year. Where gestation straddles adjacent years, we utilize a weighted average of the minimum wage based on the start of each trimester. ${ }^{13}$ All other time-varying state variables are matched based on state and year of pregnancy.

to 0.95 . Our results are not sensitive to which measure of the median wage is used to normalize the minimum wage.

${ }^{10}$ For instance, since the minimum wage is a wage floor, if the ratio of the minimum wage to the median hourly wage was one, then this would suggest that $50 \%$ of workers in the state earned the minimum wage. In this case, an increase in the nominal minimum wage would be much more binding and lead to strong labor market and income effects.

${ }^{11}$ In practice, whether we divide by the median wage at time ( $\left.\mathrm{t}\right)$ or time ( $\left.\mathrm{t}-1\right)$ does not make much of a difference.

${ }^{12}$ Specifically, we deflate by the national consumer price index for all urban consumers. Later we assess sensitivity to these alternate characterizations of the minimum wage.

${ }^{13}$ For instance, if the start of the first trimester is in year $(\mathrm{t})$ and the start of the second and third trimesters is in year $(\mathrm{t}+1)$, the average minimum wage will be $(1 / 3) * \mathrm{MW}_{\mathrm{t}}+(2 / 3) * \mathrm{MW}_{\mathrm{t}+1}$. Thus, the estimates capture effects on infant health from a mother's exposure to the higher minimum wage over her entire pregnancy. This allows for the minimum wage to have the maximal effect on infant health by shifting early prenatal inputs such as initiation of prenatal care and prenatal smoking. For instance, evidence suggests that prenatal smoking is most responsive during the first trimester (Colman, Grossman, \& Joyce, 2003; Colman \& Joyce, 2003). Results are generally not sensitive to matching the minimum wage based on year of pregnancy $(t)$, utilizing number of months-weighted average across years $(t)$ and $(t+1)$, or utilizing a simple average of the minimum wage at the start of pregnancy and at the time of birth.

Estimates for preterm birth are more sensitive to the latter two measures, partly reflecting a matching bias due to the fact that births that are not preterm, and which were conceived during the $2 \mathrm{nd}$ or $3^{\text {rd }}$ quarters of 


\section{5.c. Policy Controls}

In addition to the minimum wage, our regression model includes controls for other state policies that may affect infant health. We follow the standard in the welfare reform literature (see for instance Blank, 2002; Dave, Corman, \& Reichman, 2012; Schoeni \& Blank, 2000) and include dichotomous indicators for whether a given state in a given year had a statewide waiver in place that substantially altered the nature of AFDC with respect to time limits, sanctions, or work requirements. We also include a dichotomous indicator for whether the state had implemented TANF in time period t. ${ }^{14}$ Data on whether states had waivers and when they enacted TANF come from U.S. Department of Health \& Human Services (1997; 1999). We control for state EITC legislation via three measures: 1) an indicator for whether the state had an EITC program; 2) an indicator for whether this state's EITC is refundable, which means that the state will refund the credit if no taxes are owed; and 3) state EITC as a percentage of federal credit. In the late 1980s through the early 1990s, about one-third to half of the states which offered a tax credit made it refundable. In 2012, virtually all states' (20 out of 24) EITC's were refundable. We obtain information on states' EITC programs from Tax Credits for Working Families, Tax Policy Center of the Urban Institute and Brookings Institution, and the National Conference of State Legislatures. ${ }^{15}$ We also control for the Medicaid income eligibility expansions for

\footnotetext{
year $t$ are more likely to culminate in year $(\mathrm{t}+1)$, whereas conception and occurrence of preterm births are more likely to take place in year $(\mathrm{t})$. We confirm that effects for gestation and preterm birth are robust to matching the minimum wage by year of pregnancy, which would not be susceptible to this matching bias. ${ }^{14}$ For states which implemented an earlier waiver to their AFDC programs, the AFDC indicator is set to 0 when these states later implement TANF.

${ }^{15} \mathrm{See}$. http://www.taxcreditsforworkingfamilies.org/earned-income-tax-credit/states-with-eitcs/; http://www.taxpolicycenter.org/statistics/state-eitc-based-federal-eitc; http://www.ncsl.org/research/laborand-employment/earned-income-tax-credits-for-working-families.aspx.
} 
pregnant women which occurred during the late-1980s through mid-1990s by including the fraction of women who would be eligible for Medicaid in a given state during each period. ${ }^{16}$

\section{5.d. Sample Description}

Table 2 presents means for the baseline period (all births occurring in 1989, covering pregnancies in 1988 and 1989, through 2012) for subgroups defined by education, race, and age. Birth outcomes (birth weight, low birth weight, preterm birth) are significantly worse among lower-educated mothers (less than high school educated vs. high school graduates), non-white mothers (vs. whites), and younger mothers (ages 18-29 vs. older mothers). The average nominal minimum wage over this period was $\$ 5.21$, which in 2012 dollars amounted to $\$ 6.97$. In relative terms, the minimum wage on average represented about $44 \%$ of the median state wage.

\section{Results}

\section{6.a. Infant Health}

Table 3 presents estimates of the effect of minimum wages on birth weight. Three measures are used: birth weight in grams, indicator of low birth weight $(<2500$ grams $)$ and fetal growth (birth weight divided by gestational age). Each cell in Table 3 represents the effect of a $10 \%$ increase in the relative minimum wage (ratio of the minimum wage to the one year lagged state median wage). Estimates are obtained for several sub-groups defined by education, race, age and marital status. As the average median wage was $\$ 12.50$ over our sample period, a $10 \%$ increase in the minimum wage relative to the median wage would represent an approximately $\$ 1.25$ increase.

\footnotetext{
${ }^{16}$ See Dave et al. (2015a, 2015b) for further details on this variable.
} 
The first two columns show results for mothers with less than a high school degree. ${ }^{17}$ For this group we show results from two model specifications: with and without state-specific, time-varying variables such as the state EITC and Medicaid policy. As the addition of state-specific, time-varying factors has relatively little impact, which is supportive of the validity of the research design, we discuss only estimates that include these variables. Estimates in column 2 indicate that a 10\% increase in the relative minimum wage is associated with a 10 gram increase in birth weight; a 0.2 percentage point decrease in low birth weight; and a 0.2 gram increase in fetal growth. While statistically significant, these associations imply small effects, for example, a $2 \%$ decrease in low birth weight.

The next two columns show estimates for mothers with a high school degree. Estimates are similar. A $10 \%$ increase in the relative minimum wage is associated with a 16 gram increase in birth weight; a 0.3 percentage point decrease in low birth weight; and a 0.2 gram increase in fetal growth. Again, while associations are statistically significant they are small in magnitude.

\footnotetext{
${ }^{17}$ Appendix Table A2 reports the coefficients for the full models for birth weight. These estimates generally imply effects consistent with prior studies. Birth weight increases with the educational attainment of the mother, and is higher among mothers who are white (relative to black or other race), Hispanic, and married. Offering a refundable state EITC is associated with a higher birth weight (6-13 grams), though only the effect for less than high school educated mothers is statistically significant. However, an increase in the state's EITC generosity is significantly and positively associated with infant health for all reported groups. Welfare reform is adversely associated with infant health, with both early AFDC waivers and later TANF implementation related to a decline in birth weight by 5-25 grams. This is consistent with Kaestner and Lee (2005), who find that the reduction in caseloads associated with welfare reform may be associated with decreases in prenatal care and an increase in low birth weight. Finally, we do not find any evidence that expanded Medicaid eligibility is significantly associated with increases in mean birth weight; prior studies have been generally mixed on the effectiveness of these expansions in improving infant health (Currie and Gruber 1996; Howell 2001; Dave et al. 2008). The mean birth weight among higher educated mothers is insignificant with confidence intervals that do not include one, suggesting that higher educated mothers would not be a valid counterfactual within a DDD framework.
} 
To put the magnitudes of the effect in terms of income changes, we construct and report in Table 3 an implied instrumental variables (IV) estimate under the assumption that the earnings effect from a higher minimum wage represents the only causal pathway linking the minimum wage to infant health. "First-stage" estimates derived from the CPS (presented in Appendix Table A1) suggest that a $\$ 1$ increase in the minimum wage raises household income for women with less than a high school degree by $\$ 682$ and for women with a high school degree by $\$ 1126 .{ }^{18}$ Higher minimum wage rates are associated with a significant increase in household income for all subgroups, with the exception of married mothers. For mothers with a high school degree, this translates into an implied IV estimate of about a 12 gram $(0.4 \%$ relative to the mean) increase in birth weight and 0.2 percentage point (2.8\%) decrease in low birth weight resulting from a $\$ 1000$ increase in household income. ${ }^{19}$ This "treatment on the treated" (TOT) estimate presumes that the only channel through which the minimum wage may affect infant health is through a change in household income.

Implicit TOT estimates rescaled in this manner should be interpreted with caution because small changes in the denominator (in this case, the first-order effect of the

\footnotetext{
${ }^{18}$ The first stage estimates include both employed and non-employed women (that is, women with zero earnings). Household income includes earnings of all household members. Thus, this is a mean effect of the minimum wage at the household level that conflates both any potential decrease in employment due to the minimum wage (though prior research has not reached any consensus on this issue) and any increase in earnings among those who are employed. Appendix Table A1 also reports that a higher minimum wage significantly raises annual earnings (which includes the earnings for the spouse if the mother is married, though not the earnings of other household members) as well as the earned hourly wage rate. ${ }^{19}$ Note that the reported coefficient of the relative minimum wage (16.17 in Table 3; effect on birth weight for high school educated mothers, controlling for the state time-varying covariates) represents the effect of a $10 \%$ increase in the minimum wage relative to the median wage, or about a $\$ 1.25$ increase in the level of the minimum wage (as the median wage over the sample period is $\$ 12.50$ ). Thus, the implied IV estimate equals $[((16.17 / 1.25) * 1000) / 1126]=11.5$ grams associated with a 1000 increase in income.
} 
minimum wage on income) and the underlying estimates can lead to large differences. Nonetheless, it is a useful exercise to place our minimum wage effect in context and compare it to effects derived from another major income transfer program, namely the federal EITC. Hoynes et al. (2015) study the effects of expansions in the federal EITC, which also increased income (and employment) among eligible households, on infant health outcomes. They estimate that the effect of a $\$ 1000$ increase in income induced by the EITC expansions on birth weight was 6.4 grams $(0.2 \%$ increase relative to the mean) among low-educated single mothers. Thus, our estimate of 9.9 grams $(0.3 \%)$ for single mothers with at most a high school (HS) education is similar.

As suggested in Table 1, certain subgroups of low-educated mothers are more likely to earn an hourly wage, and specifically earn an hourly wage close to the minimum wage, and thus more likely to be affected by increases in the minimum wage. The remaining columns in Table 3 present results for different groups of low-educated $(\leq \mathrm{HS})$ mothers. Estimates from samples stratified by race indicate that the effects of a minimum wage increase are larger for non-white mothers than white mothers. In fact, the decrease in low birth weight among non-white mothers associated with a $10 \%$ increase in the normalized minimum wage is relatively large representing a $4.6 \%$ decrease in low birth weight. The implied IV estimate of a $\$ 1000$ increase in income is a 21 gram increase in birth weight and a 0.5 percentage point decrease in the likelihood of delivering a low birth weight infant for non-white mothers. ${ }^{20}$ The minimum wage is associated with larger effects on birth weight for young mothers (ages 18 to 29) relative to older mothers (ages 30 to 39), but all

\footnotetext{
${ }^{20}$ The comparable estimates from the EITC literature for low-educated non-white mothers are 19-28 grams (continuous birth weight) and a decline of 0.8 to 1.1 percentage points in low birth weight.
} 
estimates remain relatively small. Finally, estimates of the effect of the minimum wage on birth weight are slightly larger for unmarried mothers than married mothers. While the heterogeneity of estimates is not that large, it is consistent with the figures in Table 1 . As shown in Table 1, younger and non-white mothers are the most likely to be affected by minimum wage changes.

Higher birth weight may reflect either an improvement in fetal growth and/or an increase in gestational age (reduction in preterm birth). We show estimates of the effect of the minimum wage on gestational age (measured in weeks) and preterm birth in Table 4, which has the same format as Table 3. Estimates in Table 4 indicate that a higher minimum wage is associated with a small increase in gestational age and a small decrease in the likelihood of a preterm birth. Specifically, among mothers with a high school degree, a 10\% increase in the relative minimum wage (corresponding to approximately a $\$ 1.25$ increase) is associated with an additional 0.1 week of gestation $(0.3 \%)$, and a 0.39 percentage point decrease (3.3\% relative to the mean) in the probability of delivering an infant prior to 37 weeks of pregnancy. These estimates imply a TOT effect of a 0.28 percentage point $(2.4 \%)$ decline in preterm birth associated with a $\$ 1000$ increase in income for mothers with a high school degree. As estimates in the remaining columns of Table 4 indicate, there is relatively little heterogeneity in the effect of the minimum wage on gestation by race, age and marital status.

\section{6.b. Prenatal Inputs}

The results from Tables 3 and 4 consistently suggest some improvements in infant health. While several causal channels may underlie these effects, many of which are not observed in the natality files, we are able to test whether the improved infant health is 
consistent with effects on prenatal inputs. Estimates in Table 5 examine two possible mechanisms through which the minimum wage may have improved infant health: prenatal care and smoking. These estimates indicate that an increase in the minimum wage is associated with an increase in prenatal care, particularly among mothers with less than a high school degree. Among this group, a 10\% increase in the minimum wage is associated with a 1.4 percentage point (13.5\%) decrease in the probability of having less than five prenatal visits over the course of the pregnancy, and a decrease of about 0.2 month $(5.3 \%)$ in delaying prenatal care. ${ }^{21}$ Estimates are considerably smaller for mothers with a high school degree, and there is not much variation in estimates by race, age and marital status. The one exception is for non-whites; for this sample, the minimum wage is not significantly associated with prenatal care. The estimates of the effect of the minimum wage on prenatal care do not line up exactly with the estimates of the effect of the minimum wage on birth weight. It is not the case that where we see the largest changes in birth weight (gestation) we see the largest changes in prenatal care. However, confidence intervals are relatively large and such precise comparisons are not supported by the precision of estimates.

Estimates in Table 5 also indicate that an increase in the minimum wage is associated with a reduced likelihood of any prenatal smoking and smoking more than 5 cigarettes daily with relatively larger effects found for less educated, non-white and young mothers. ${ }^{22}$ Effect sizes are relatively small, for example, among mothers with less than a

\footnotetext{
${ }^{21}$ Results for number of prenatal visits are consistent with the discussion here, and presented in Appendix Table A3.

22 The decrease in prenatal smoking reflects an increase in quitting among women who smoked prior to pregnancy rather than a decrease in initiation. The majority of smokers initiate prior to age 18 , and virtually all initiate prior to age 21 . Our results are robust to excluding pregnant women ages 18-20. Furthermore, very few women start smoking during pregnancy.
} 
high school degree, a $10 \%$ increase in the relative minimum wage is associated with a 0.9 percentage point (4\%) decrease in the probability of prenatal smoking.

Estimates of the effect of the minimum wage on prenatal care and smoking are also consistent with the estimates from the EITC literature. Hoynes et al. (2015) also finds that the federal EITC expansion mostly improved infant health through reductions in prenatal smoking and expansions in prenatal care. They find that a $\$ 1000$ increase in income (associated with the EITC expansion) reduced the likelihood of prenatal smoking by about one percentage point ( $4.1 \%$ relative to the mean). Our estimates suggest that a $\$ 1000$ increase in income (associated with the higher minimum wage) also reduced the probability of smoking during pregnancy among mothers with less than a high school degree by about one percentage point ( $4.7 \%$ relative to the sample mean). ${ }^{23}$ Averett and Wang (2013) also find that the income effect induced by the federal EITC expansion reduced maternal smoking. The implied negative relationship between smoking and income that we and others found suggests that smoking is an inferior good, which is an issue still debated in the literature (e.g., Kenkel, Schmeiser, \& Urban, 2014). However, as we described earlier there are other causal mechanisms besides income that links minimum wage to infant health and maternal health behaviors. For example, the increases in prenatal care we observe may decrease maternal smoking because of greater contact with physicians.

\footnotetext{
${ }^{23}$ Note that the first-stage effect (Appendix Table A1) suggests that a $\$ 1$ increase in the minimum wage raised household income by $\$ 682$ among less than high school educated mothers. The effect on prenatal smoking is estimated to be a 0.009 (Table 5 Column 2) reduction in the probability of any smoking during pregnancy, associated with a $10 \%$ increase in the relative minimum wage (about a $\$ 1.25$ increase). Thus the implied IV effect of a $\$ 1000$ increase in income is: $[((-0.009 / 1.25) * 1000) / 682]=-0.011$.
} 


\section{6.c. Additional Specifications}

We conducted additional analyses to assess specific issues and gauge the plausibility of our estimates. First, we assess whether the minimum wage only affects infant health and prenatal inputs contemporaneously or whether it also has cumulative effects which may occur through impacting maternal health or savings prior to pregnancy. Panel A of Table 6 reports the results for the contemporaneous specification (based on matching the relative minimum wage over the pregnancy period) for each outcome that we have discussed above as a reference. Panel B reports effects of the mean relative minimum wage, measured over the pregnancy period plus over the two years prior to conception. Thus, these effects capture both the contemporaneous as well as any cumulative effects operating through changes in maternal health up to two years prior to pregnancy. If there are no lasting effects of prior increases in the minimum wage on infant health, then the coefficients of these broader minimum wage measures would decline. However, we find that the effect sizes generally become larger across virtually all measures of infant health and prenatal inputs, and the increase is monotonic when comparing the contemporaneous effects (Panel A) to effects up to two years (Panel B) or up to three years (not reported) prior to pregnancy. Thus, there is suggestive evidence that increases in the minimum wage can improve infant health and health-promoting prenatal inputs both during the period of pregnancy as well as through persistent effects presumably operating through improvements in maternal health and household finances.

Second, in Panel D of Table 6, we extend the specifications to estimate lead effects of increases in the minimum wage for up to three years after the pregnancy. Including leads of the minimum wage allows us to evaluate whether trends in outcomes prior to the change 
in a state's minimum wage policy are significantly different across the treated and control states. As revealed in Table 6, the effects of the minimum wage remain stable in terms of both magnitudes and significance. Second, the majority of the lead effects are statistically insignificant, and generally of a much smaller magnitude than the main effects. These patterns suggest that the DD research design is internally valid.

Third, we assess the sensitivity of our estimates to alternate measures of the minimum wage. Specifically, we consider two measures which are not normalized by the state's median wage: the mean nominal minimum wage over the pregnancy period, and the mean real minimum wage over the pregnancy period. We note that even with the mean "nominal" minimum wage the inclusion of the year fixed effects captures national changes in the price level, but with the second measure we are also assessing effects of the real minimum wage parametrically deflated by the consumer price index and expressed in constant 2012 dollars. The estimates across these alternate characterizations are presented in Appendix Table A4. While the coefficients expectedly change from the rescaling of the minimum wage, all of the estimates remain consistent in terms of direction of the effects, statistical significance, and patterns across subgroups. In order to compare effect magnitudes across these different measures, we computed the elasticity of each outcome with respect to each of the minimum wage transforms and the implied IV effects; these estimates were highly similar across the alternate characterizations.

\section{Conclusion}

The debate over the merits of a minimum wage and over the level of the minimum wage have been frequent and ongoing for decades. Most of that debate is focused on the labor market effects of the minimum wage with employment being the most oft debated 
outcome. However, the increase in income associated with the minimum wage, which is widely acknowledged for all but the least skilled persons, may have benefits in other domains. Here we examined whether the minimum wage affected infant health.

Our results suggest a small, significant and beneficial effect of a minimum wage increase on birth weight due to both a decrease in preterm birth (increase in gestation) and increase in fetal growth (gestation-adjusted birth weight). For mothers with a high school degree, estimates suggest that an increase in the minimum wage that causes a $\$ 1000$ increase in annual household income is associated with a 12 gram $(0.4 \%$ relative to the mean) increase in birth weight and 0.2 percentage point (2.8\%) decrease in low birth weight. We found similar effect sizes for other demographic groups with slightly larger effects observed for younger, non-white and unmarried mothers.

Results also identified two potential pathways that are consistent with the beneficial effect of the minimum wage on infant health: greater prenatal care and reduced maternal smoking. Again, the effect of the minimum wage on these health behaviors is relatively small, but significant. For example, an increase in the minimum wage that causes a $\$ 1000$ increase in income reduced the likelihood of prenatal smoking by about one percentage point for a mother with less than a high school degree.

Our findings are broadly consistent with estimates of the effect of the EITC on infant health, which is another policy that affects incomes of low-wage workers. Thus, there is a growing body of evidence that labor market policies that enhance wages can affect wellbeing in broader ways than often considered. These "other" effects of the minimum wage should enter the debate over its merits. 


\section{References}

Aaronson, D. (2001). Price pass-through and the minimum wage. Review of Economics and statistics, 83(1), 158-169.

Aaronson, D., Agarwal, S., \& French, E. (2012). The Spending and Debt Response to Minimum Wage Hikes. The American Economic Review, 3111-3139.

Addison, J. T., Blackburn, M. L., \& Cotti, C. D. (2012). The Effect of Minimum Wages on Labour Market Outcomes: County-Level Estimates from the Restaurant-and-Bar Sector. British Journal of Industrial Relations, 50(3), 412-435.

Autor, D. H., Katz, L. F., \& Kearney, M. S. (2008). Trends in US wage inequality: Revising the revisionists. The Review of Economics and Statistics, 90(2), 300-323.

Averett, S., \& Wang, Y. (2013). The effects of Earned Income Tax Credit payment expansion on maternal smoking. Health Economics, 22(11), 1344-1359.

Basker, E., \& Khan, M. T. (2013). Does the Minimum Wage Bite into Fast-Food Prices? Available at SSRN 2326659.

Baughman, R. (2012). The effects of state EITC expansion on children's health. The Carsey School of Public Policy at the Scholars' Repository, National Issue Brief No. 48(Paper 168).

Baughman, R. A., \& Duchovny, N. (2016). State earned income tax credits and the production of child health: Insurance coverage, utilization, and health status. National Tax Journal, 69(1), 103-131. doi:10.17310/ntj.2016.1.04

Belman, D., Wolfson, P., \& Nawakitphaitoon, K. (2015). Who Is Affected by the Minimum Wage? Industrial Relations: A Journal of Economy and Society, 54(4), 582-621. 
Bertrand, M., Duflo, E., \& Mullainathan, S. (2004). How Much Should We Trust Differencesin-Differences Estimates? Quarterly Journal of Economics, 119(1).

Blank, R. M. (2002). Evaluating Welfare Reform in the United States. Journal of Economic Literature, 40(4), 1105-1166.

Byrne, D., \& Mazanov, J. (2016). Smoking and Cardiovascular Risk: Role of Stress in the Genesis of Smoking Behavior. Handbook of Psychocardiology, 79-97.

Camacho, A. (2008). Stress and birth weight: evidence from terrorist attacks. The American Economic Review, 98(2), 511-515.

Card, D. (1992). Using regional variation in wages to measure the effects of the federal minimum wage. Industrial \& Labor Relations Review, 46(1), 22-37.

Card, D., \& DiNardo, J. E. (2002). Skill biased technological change and rising wage inequality: some problems and puzzles. Retrieved from

Card, D., \& Krueger, A. B. (1994). Minimum Wages and Employment: A Case Study of the Fast-Food Industry in New Jersey and Pennsylvania. The American Economic Review, 84(4), 772-793.

Clemens, J. P. (2015). The Minimum Wage and the Great Recession: Evidence from the Current Population Survey. NBER Working Paper(w21830).

Colman, G., Grossman, M., \& Joyce, T. (2003). The effect of cigarette excise taxes on smoking before, during and after pregnancy. Journal of Health Economics, 22(6), 1053-1072.

Colman, G. J., \& Joyce, T. (2003). Trends in smoking before, during, and after pregnancy in ten states. American journal of preventive medicine, 24(1), 29-35. 
Congressional Budget Office. (2014). The Effects of a Minimum-Wage Increase on Employment and Family Income. Retrieved from https://www.cbo.gov/publication/44995

Corman, H., Dave, D. M., Das, D., \& Reichman, N. E. (2013). Effects of welfare reform on illicit drug use of adult women. Economic inquiry, 51(1), 653-674.

Cowan, B., \& Tefft, N. (2012). Education, maternal smoking, and the earned income tax credit. The BE Journal of Economic Analysis \& Policy, 12(1).

Currie, J., \& Gruber, J. (1996). Saving Babies: The Efficacy and Cost of Recent Changes in the Medicaid Eligibility of Pregnant Women. Journal of Political Economy, 1263-1296.

Dave, D. M., Corman, H., \& Reichman, N. E. (2012). Effects of welfare reform on education acquisition of adult women. Journal of labor research, 33(2), 251-282.

Dave, D. M., Decker, S., Kaestner, R., \& Simon, K. I. (2008). Re-examining the Effects of Medicaid Expansions for Pregnant Women. National Bureau of Economic Research Working Paper Series, No. 14591. doi:10.3386/w14591

Dave, D. M., Decker, S. L., Kaestner, R., \& Simon, K. I. (2010). The effect of Medicaid expansions on the health insurance coverage of pregnant women: An analysis using deliveries. INQUIRY: The Journal of Health Care Organization, Provision, and Financing, 47(4), 315-330.

David, H., Manning, A., \& Smith, C. L. (2016). The contribution of the minimum wage to US wage inequality over three decades: a reassessment. American Economic Journal: Applied Economics, 8(1), 58-99. 
DiNardo, J., Fortin, N. M., \& Lemieux, T. (1996). Labor Market Institutions and the Distribution of Wages, 1973-1992: A Semiparametric Approach. Econometrica, 64(5), 1001-1044.

Dube, A., Lester, T. W., \& Reich, M. (2010). Minimum wage effects across state borders: Estimates using contiguous counties. The Review of Economics and Statistics, 92(4), $945-964$.

Dube, A., Naidu, S., \& Reich, M. (2007). The economic effects of a citywide minimum wage. Industrial \& Labor Relations Review, 60(4), 522-543.

Evans, W. N., \& Garthwaite, C. L. (2014). Giving Mom a Break: The Impact of Higher EITC Payments on Maternal Health. American Economic Journal: Economic Policy, 6(2), 258-290.

Horn, B., Strain, M., \& Maclean, J. (2016). Do minimum wage increases influence worker health? Retrieved from

Howell, E. M. (2001). The impact of the Medicaid expansions for pregnant women: a synthesis of the evidence. Medical Care Research and Review, 58(1), 3-30.

Hoynes, H., Miller, D., \& Simon, D. (2015). Income, the Earned Income Tax Credit, and Infant Health. American Economic Journal: Economic Policy, 7(1), 172-211.

Kaestner, R., \& Lee, W. C. (2005). The effect of welfare reform on prenatal care and birth weight. Health Economics, 14(5), 497-511.

Kenkel, D. S., Schmeiser, M. D., \& Urban, C. (2014). Is smoking inferior? Evidence from variation in the earned income tax credit. Journal of Human Resources, 49(4), 10941120. 
Kotelchuck, M. (1994). The Adequacy of Prenatal Care Utilization Index: its US distribution and association with low birthweight. American Journal of Public Health, 84(9), 1486-1489.

Lee, D. S. (1999). Wage inequality in the United States during the 1980s: Rising dispersion or falling minimum wage? Quarterly Journal of Economics, 977-1023.

Lemieux, T. (2002). Decomposing changes in wage distributions: a unified approach. Canadian Journal of Economics/Revue canadienne d'économique, 35(4), 646-688.

Lemieux, T. (2006). Increasing residual wage inequality: Composition effects, noisy data, or rising demand for skill? The American Economic Review, 461-498.

Lenhart, O. (2015a). Do Higher Minimum Wages Benefit Health? Evidence from the UK. Social Science Research Network Working Paper.

Lenhart, O. (2015b). The Impact of Minimum Wages on Population Health: A Comparison across OECD Countries and US States. Working Paper. Retrieved from https://ottolenhart.files.wordpress.com/2015/04/the-impact-of-minimum-wageson-population-health-a-comparison-across-oecd-countries-and-us-states1.pdf

Luttmer, E. F. (2007). Does the Minimum Wage Cause Inefficient Rationing? The BE Journal of Economic Analysis \& Policy, 7(1).

MacDonald, J. M., \& Aaronson, D. (2006). How firms construct price changes: Evidence from restaurant responses to increased minimum wages. American Journal of Agricultural Economics, 88(2), 292-307.

MaCurdy, T. (2015). How effective is the minimum wage at supporting the poor? Journal of Political Economy, 123(2), 497-545. 
Martin, J. A., Osterman, M., Kirmeyer, S., \& Gregory, E. (2015). Measuring Gestational Age in Vital Statistics Data: Transitioning to the Obstetric Estimate. National Vital Statistics Reports: From the Centers for Disease Control and Prevention, National Center for Health Statistics, National Vital Statistics System, 64(5), 1-20.

McCarrier, K. P., Zimmerman, F. J., Ralston, J. D., \& Martin, D. P. (2011). Associations between minimum wage policy and access to health care: evidence from the Behavioral Risk Factor Surveillance System, 1996-2007. American Journal of Public Health, 101(2), 359-367.

Meltzer, D. O., \& Chen, Z. (2011). The impact of minimum wage rates on body weight in the United States Economic aspects of obesity (pp. 17-34): University of Chicago Press.

Neumark, D., Salas, J. I., \& Wascher, W. (2014). Revisiting the Minimum Wage-

Employment Debate: Throwing Out the Baby with the Bathwater? Industrial \& Labor Relations Review, 67(3 suppl), 608-648.

Neumark, D., Schweitzer, M., \& Wascher, W. (2004). Minimum wage effects throughout the wage distribution. Journal of Human Resources, 39(2), 425-450.

Neumark, D., \& Wascher, W. (1992). Employment effects of minimum and subminimum wages: panel data on state minimum wage laws. Industrial \& Labor Relations Review, $46(1), 55-81$.

Nielsen, S. S., Dills, R. L., Glass, M., \& Mueller, B. A. (2014). Accuracy of prenatal smoking data from Washington State birth certificates in a population-based sample with cotinine measurements. Annals of epidemiology, 24(3), 236-239.

Pinoli, S. (2010). Rational Expectations and the Puzzling No-Effect of the Minimum Wage. IZA Discussion Paper, No. 4933. 
Powers, E. T. (2009). The Impact of Minimum-Wage Increases: Evidence from Fast-food Establishments in Illinois and Indiana. Journal of labor research, 30(4), 365-394.

Reich, M., \& Hall, P. (2001). A Small Raise for the Bottom. University of California Institute for Labor and Employment.

Reich, M., \& West, R. (2015). The Effects of Minimum Wages on Food Stamp Enrollment and Expenditures. Industrial Relations: A Journal of Economy and Society, 54(4), 668-694.

Sabia, J. J. (2008). Minimum wages and the economic well-being of single mothers. Journal of Policy Analysis and management, 848-866.

Sabia, J. J., \& Nguyen, T. T. (2015). The Effects of Minimum Wage Increases On MeansTested Government Assistance. Retrieved from https://www.epionline.org/wpcontent/uploads/2015/12/EPI_MW_GovtAssist_Study_V2.pdf

Saffer, H., \& Dave, D. (2005). Mental illness and the demand for alcohol, cocaine, and cigarettes. Economic inquiry, 43(2), 229-246.

Schoeni, R. F., \& Blank, R. M. (2000). What has Welfare Reform Accomplished? Impacts on Welfare Participation, Employment, Income, Poverty, and Family Structure. National Bureau of Economic Research Working Paper Series, No. 7627. doi:10.3386/w7627

Strully, K. W., Rehkopf, D. H., \& Xuan, Z. (2010). Effects of prenatal poverty on infant health state earned income tax credits and birth weight. American Sociological Review, 75(4), 534-562.

Tong, V. T., Dietz, P. M., Farr, S. L., D'angelo, D. V., \& England, L. J. (2013). Estimates of smoking before and during pregnancy, and smoking cessation during pregnancy: comparing two population-based data sources. Public Health Reports, 179-188 
Table 1

Hourly Wage Female Earners, Ages 18-39

Current Population Survey 1989-2012

\begin{tabular}{lcccc}
\hline Sample & $\begin{array}{c}\text { Percent Paid } \\
\text { Hourly }\end{array}$ & $\begin{array}{c}\text { Wage }< \\
1.10 * \text { Minimum } \\
\text { Wage }\end{array}$ & $\begin{array}{c}\text { Wage }< \\
1.20 * \text { Minimum } \\
\text { Wage }\end{array}$ & $\begin{array}{c}\text { Wage }< \\
1.25 * \text { Minimum } \\
\text { Wage }\end{array}$ \\
\cline { 2 - 4 } High School or Below & 80.24 & 19.28 & 30.51 & 33.94 \\
Less than High School & 82.13 & 26.12 & 40.01 & 43.60 \\
High School & 79.28 & 15.67 & 25.49 & 28.83 \\
High School or Below - White & 79.16 & 18.09 & 28.33 & 31.46 \\
High School or Below - Non-White & 82.00 & 21.14 & 33.92 & 37.81 \\
High School or Below - Non-Married & 76.64 & 14.32 & 23.48 & 26.40 \\
High School or Below - Married & 83.19 & 23.02 & 35.80 & 39.62 \\
High School or Below - Ages 18-29 & 84.51 & 24.30 & 37.73 & 41.72 \\
High School or Below - Ages 30-39 & 75.56 & 13.13 & 21.64 & 24.39 \\
\hline
\end{tabular}

Notes: Rates are estimated from the monthly CPS data and weighted by the CPS sampling weights. Sample sizes ranged from 103,932 to 303,195 . 
Table 2

Sample Means, Births 1989-2012

\begin{tabular}{|c|c|c|c|c|c|c|c|}
\hline Sample & $\begin{array}{l}\text { High school } \\
\text { grad. or } \\
\text { below } \\
\end{array}$ & $\begin{array}{l}\text { Less than } \\
\text { high school }\end{array}$ & $\begin{array}{l}\text { High school } \\
\text { grad. }\end{array}$ & White & Non-white & $\begin{array}{l}\text { Ages } \\
18-29\end{array}$ & $\begin{array}{l}\text { Ages } \\
30-39\end{array}$ \\
\hline Birth weight (grams) & 3269.125 & 3243.109 & 3284.138 & 3315.402 & 3111.748 & 3258.760 & 3303.671 \\
\hline Low birth weight & 0.082 & 0.086 & 0.080 & 0.070 & 0.125 & 0.081 & 0.088 \\
\hline $\begin{array}{l}\text { Fetal growth (birth weight / } \\
\text { gestational age in week) }\end{array}$ & 84.051 & 83.458 & 84.391 & 85.014 & 80.777 & 83.676 & 85.300 \\
\hline Gestation (weeks) & 38.783 & 38.762 & 38.794 & 38.913 & 38.341 & 38.840 & 38.591 \\
\hline Preterm birth & 0.123 & 0.130 & 0.119 & 0.109 & 0.170 & 0.120 & 0.132 \\
\hline Prenatal care visits & 10.793 & 10.047 & 11.221 & 11.011 & 10.039 & 10.723 & 11.027 \\
\hline Prenatal care visits $<5$ visits & 0.070 & 0.104 & 0.050 & 0.058 & 0.108 & 0.072 & 0.062 \\
\hline $\begin{array}{l}\text { Months delayed prenatal } \\
\text { care }\end{array}$ & 3.066 & 3.427 & 2.842 & 2.966 & 3.365 & 3.106 & 2.886 \\
\hline Any prenatal smoking & 0.190 & 0.226 & 0.171 & 0.208 & 0.134 & 0.197 & 0.167 \\
\hline Smoking $>5$ cigarettes daily & 0.132 & 0.160 & 0.117 & 0.151 & 0.071 & 0.134 & 0.122 \\
\hline Minimum wage (nominal) & 5.206 & 5.283 & 5.162 & 5.210 & 5.193 & 5.186 & 5.273 \\
\hline Minimum wage (2012 \$) & 6.973 & 7.003 & 6.956 & 6.986 & 6.927 & 6.956 & 7.028 \\
\hline $\begin{array}{l}\text { Minimum wage (relative to } \\
1 \text {-year lagged median wage) }\end{array}$ & 0.437 & 0.437 & 0.437 & 0.438 & 0.434 & 0.438 & 0.433 \\
\hline Age & 25.375 & 24.724 & 25.750 & 25.515 & 24.899 & 23.031 & 33.185 \\
\hline Less than high school & 0.346 & 1 & 0 & 0.375 & 0.335 & 0.379 & 0.321 \\
\hline High school graduate & 0.634 & 0 & 1 & 0.625 & 0.665 & 0.621 & 0.679 \\
\hline White & 0.773 & 0.792 & 0.761 & 1.000 & 0.000 & 0.767 & 0.792 \\
\hline Black & 0.181 & 0.164 & 0.191 & 0.000 & 0.797 & 0.192 & 0.145 \\
\hline Other race & 0.046 & 0.044 & 0.047 & 0.000 & 0.203 & 0.041 & 0.062 \\
\hline Hispanic & 0.295 & 0.476 & 0.190 & 0.368 & 0.046 & 0.288 & 0.319 \\
\hline Married & 0.533 & 0.450 & 0.581 & 0.601 & 0.304 & 0.483 & 0.701 \\
\hline Cigarette excise tax & 58.030 & 60.316 & 56.712 & 58.123 & 57.712 & 56.672 & 62.559 \\
\hline State EITC & 0.187 & 0.173 & 0.194 & 0.178 & 0.216 & 0.180 & 0.208 \\
\hline $\begin{array}{l}\text { State refundable EITC (State } \\
\text { EITC }=1 \text { ) }\end{array}$ & 0.829 & 0.850 & 0.825 & 0.820 & 0.856 & 0.828 & 0.846 \\
\hline $\begin{array}{l}\% \text { of Federal EITC (State } \\
\text { EITC }=1 \text { ) }\end{array}$ & 16.225 & 15.844 & 16.505 & 15.421 & 18.588 & 15.950 & 17.197 \\
\hline AFDC Waiver & 0.075 & 0.083 & 0.070 & 0.078 & 0.064 & 0.072 & 0.083 \\
\hline TANF & 0.584 & 0.608 & 0.571 & 0.582 & 0.593 & 0.584 & 0.587 \\
\hline Medicaid eligibility fraction & 0.474 & 0.479 & 0.471 & 0.474 & 0.474 & 0.472 & 0.482 \\
\hline Observations & $45,799,136$ & $16,757,859$ & $29,041,277$ & $35,387,017$ & $10,412,119$ & $35,228,487$ & $10,570,649$ \\
\hline
\end{tabular}

Notes: Sample means are reported. Observations represent maximum sample size. For some variables, notably the prenatal smoking measures, samples sizes are smaller due to missing information (see text). 
Table 3

Effect of the Relative Minimum Wage on Birth Weight

\begin{tabular}{|c|c|c|c|c|c|c|c|c|c|c|}
\hline \multirow[b]{3}{*}{ Birth weight (grams) } & \multirow{2}{*}{$\begin{array}{l}\text { Less than High } \\
\text { School }\end{array}$} & \multirow{2}{*}{$\begin{array}{l}\text { Less than High } \\
\text { School }\end{array}$} & \multirow[t]{2}{*}{ High School } & \multirow[t]{2}{*}{ High School } & \multicolumn{6}{|c|}{ High School or Below } \\
\hline & & & & & White & Non-White & Age $18-29$ & Age 30-39 & Married & Not Married \\
\hline & & & & & & & & & & \\
\hline Minimum wage & $\begin{array}{c}11.92 * * * \\
(4.45)\end{array}$ & $\begin{array}{c}10.00 * * * \\
(3.00)\end{array}$ & $\begin{array}{c}18.67 * * * \\
(2.56)\end{array}$ & $\begin{array}{c}16.17 * * * \\
(2.32)\end{array}$ & $\begin{array}{c}12.03 * * * \\
(2.05)\end{array}$ & $\begin{array}{c}22.41 * * * \\
(3.77)\end{array}$ & $\begin{array}{c}15.10^{* * * *} \\
(2.28)\end{array}$ & $\begin{array}{l}6.87 * * \\
(3.15)\end{array}$ & $\begin{array}{c}12.13 * * * \\
(2.23)\end{array}$ & $\begin{array}{c}13.95^{* * *} \\
(2.70)\end{array}$ \\
\hline \multirow{2}{*}{$\begin{array}{r}\text { Implied IV (\$1000 } \\
\text { income increase) } \\
\text { Sample mean }\end{array}$} & 14.0 & 11.7 & 13.3 & 11.5 & 10.3 & 20.8 & 13.6 & 7.6 & - & 9.9 \\
\hline & 3243.1 & 3243.1 & 3284.1 & 3284.1 & 3315.4 & 3111.7 & 3258.8 & 3303.7 & 3334.6 & 3194.3 \\
\hline \multicolumn{11}{|l|}{ Low birth weight } \\
\hline Minimum wage & $\begin{array}{c}-0.0025^{*} \\
(0.001)\end{array}$ & $\begin{array}{c}-0.0017 * \\
(0.001)\end{array}$ & $\begin{array}{c}-0.0037 * * * \\
(0.001)\end{array}$ & $\begin{array}{c}-0.0031^{* * *} \\
(0.001)\end{array}$ & $\begin{array}{c}-0.0018^{* * *} \\
(0.001)\end{array}$ & $\begin{array}{c}-0.0057^{* * * *} \\
(0.001)\end{array}$ & $\begin{array}{c}-0.0026^{* * *} \\
(0.001)\end{array}$ & $\begin{array}{c}-0.0018^{*} \\
(0.001)\end{array}$ & $\begin{array}{c}-0.0017^{* * * *} \\
(0.001)\end{array}$ & $\begin{array}{c}-0.0032 * * * \\
(0.001)\end{array}$ \\
\hline $\begin{array}{l}\text { Implied IV ( } \$ 1000 \\
\text { income increase) }\end{array}$ & -0.0029 & -0.0020 & -0.0026 & -0.0022 & -0.0015 & -0.0053 & -0.0024 & -0.0020 & - & -0.023 \\
\hline Sample Mean & 0.086 & 0.086 & 0.080 & 0.080 & 0.070 & 0.125 & 0.081 & 0.088 & 0.067 & 0.100 \\
\hline \multicolumn{11}{|l|}{ Fetal growth } \\
\hline Minimum wage & $\begin{array}{c}0.19^{* * *} \\
(0.05)\end{array}$ & $\begin{array}{c}0.15^{* * * *} \\
(0.04)\end{array}$ & $\begin{array}{c}0.28 * * * \\
(0.04)\end{array}$ & $\begin{array}{c}0.24 * * * \\
(0.04)\end{array}$ & $\begin{array}{c}0.14 * * * \\
(0.03)\end{array}$ & $\begin{array}{c}0.39 * * * \\
(0.07)\end{array}$ & $\begin{array}{c}0.22 * * * \\
(0.04)\end{array}$ & $\begin{array}{c}0.08 \\
(0.06)\end{array}$ & $\begin{array}{c}0.15^{* * * *} \\
(0.03)\end{array}$ & $\begin{array}{c}0.23 * * * \\
(0.05)\end{array}$ \\
\hline \multirow{2}{*}{$\begin{array}{r}\text { Implied IV (\$1000 } \\
\text { income increase) } \\
\text { Sample Mean }\end{array}$} & 0.22 & 0.18 & 0.20 & 0.17 & 0.12 & 0.36 & 0.20 & 0.09 & - & 0.16 \\
\hline & 83.458 & 83.458 & 84.391 & 84.391 & 85.014 & 80.777 & 83.676 & 85.300 & 85.502 & 82.391 \\
\hline $\begin{array}{l}\text { Includes time- } \\
\text { varying } \\
\text { State controls }\end{array}$ & No & Yes & No & Yes & Yes & Yes & Yes & Yes & Yes & Yes \\
\hline $\begin{array}{l}\text { Notes: Coefficients fro } \\
\text { arbitrary correlation in } \\
\text { following individual-s } \\
\text { unemployment rate, } \mathrm{m} \\
\text { waiver, indicator for } \mathrm{T} \\
\text { million to } 45.3 \text { million } \\
<\text { p-value } \leq 0.10\end{array}$ & $\begin{array}{l}\text { OLS models are } \\
\text { errors across o } \\
\text { ific covariates: } \\
\text { wage rate for } n \\
F \text {, fraction of } p 1 \\
\text { servations. See }\end{array}$ & $\begin{array}{l}\text { oorted. Each cel } \\
\text { rvations within } \\
\text { icators for age, } r \\
\text { es, mean wage } r \\
\text { nant women elis } \\
\text { pendix A1 for } \mathrm{f}\end{array}$ & $\begin{array}{l}\text { resents the e } \\
\text { state, and re } \\
\text { ethnicity, m } \\
\text { pr females, ir } \\
\text { for Medicaic } \\
\text { esults for the }\end{array}$ & $\begin{array}{l}\text { f a } 10 \% \text { inc } \\
\text { in parenth } \\
\text { status, and e } \\
\text { or for state } 1 \\
\text { the mean or } \\
\text { ariates. As }\end{array}$ & $\begin{array}{l}\text { n the minir } \\
\text { ll specifica } \\
\text { onal attain } \\
\text { indicator fo } \\
\text { rate amon } \\
\text { denote sta }\end{array}$ & $\begin{array}{l}\text { wage relati } \\
\text { control sta } \\
\text { and the fol } \\
\text { indable sta } \\
\text { rried colleg } \\
\text { l significar }\end{array}$ & $\begin{array}{l}\text { the median } \\
\text { d year of pre } \\
\text { lg state-spec } \\
\text { TC, state EI } \\
\text { lcated moth } \\
\text { follows: ** }\end{array}$ & $\begin{array}{l}\text { (see text) } \\
\text { cy fixed e } \\
\text { ovariates: } \\
\text { a \% of fe } \\
\text { as } 25-39 \text {. } \\
\text { alue } \leq 0.0\end{array}$ & $\begin{array}{l}\text { dard errors } \\
\text { loyment-to- } \\
\text { EITC, indic } \\
\text { ple sizes rat } \\
0.01<\text { p-va }\end{array}$ & $\begin{array}{l}\text { adjusted for } \\
\text { nclude the } \\
\text { llation ratio, } \\
\text { for AFDC } \\
\text { from } 10.3 \\
\leq 0.05 ; * 0.05\end{array}$ \\
\hline
\end{tabular}


Table 4

Effect of the Relative Minimum Wage on Gestation

\begin{tabular}{|c|c|c|c|c|c|c|c|c|c|c|}
\hline \multirow{3}{*}{ Gestation Weeks } & \multirow{2}{*}{$\begin{array}{c}\text { Less than } \\
\text { High School }\end{array}$} & \multirow{2}{*}{$\begin{array}{c}\text { Less than } \\
\text { High School }\end{array}$} & \multirow[t]{2}{*}{ High School } & \multirow[t]{2}{*}{ High School } & \multicolumn{6}{|c|}{ High School or Below } \\
\hline & & & & & White & Non-White & Age $18-29$ & Age 30-39 & Married & Not Married \\
\hline & & & & & & & & & & \\
\hline Minimum wage & $\begin{array}{c}0.11^{* * *} \\
(0.02)\end{array}$ & $\begin{array}{c}0.10^{* * *} \\
(0.02)\end{array}$ & $\begin{array}{c}0.12 * * * \\
(0.02)\end{array}$ & $\begin{array}{c}0.11^{* * *} \\
(0.02)\end{array}$ & $\begin{array}{c}0.11^{* * *} \\
(0.02)\end{array}$ & $\begin{array}{c}0.11^{* * *} \\
(0.02)\end{array}$ & $\begin{array}{c}0.11^{* * *} \\
(0.02)\end{array}$ & $\begin{array}{c}0.09 * * * \\
(0.02)\end{array}$ & $\begin{array}{c}0.12 * * * \\
(0.02)\end{array}$ & $\begin{array}{c}0.09 * * * \\
(0.02)\end{array}$ \\
\hline \multirow{2}{*}{$\begin{array}{r}\text { Implied IV ( } \$ 1000 \\
\text { income increase) } \\
\text { Sample mean }\end{array}$} & 0.13 & 0.12 & 0.09 & 0.08 & 0.09 & 0.10 & 0.10 & 0.10 & - & 0.06 \\
\hline & 38.8 & 38.8 & 38.8 & 38.8 & 38.9 & 38.3 & 38.8 & 38.6 & 38.9 & 38.6 \\
\hline \multicolumn{11}{|l|}{ Preterm $($ Weeks $<37)$} \\
\hline Minimum wage & $\begin{array}{l}-0.0043 * * * \\
(0.001)\end{array}$ & $\begin{array}{l}-0.0033^{* *} \\
(0.002)\end{array}$ & $\begin{array}{c}-0.0044 * * * \\
(0.001)\end{array}$ & $\begin{array}{c}-0.0039 * * * \\
(0.001)\end{array}$ & $\begin{array}{c}-0.0049 * * * \\
(0.002)\end{array}$ & $\begin{array}{l}-0.0028 \\
(0.002)\end{array}$ & $\begin{array}{l}-0.0038^{* * *} \\
(0.001)\end{array}$ & $\begin{array}{c}-0.0045^{* * *} \\
(0.002)\end{array}$ & $\begin{array}{l}-0.0053 * * * \\
(0.002)\end{array}$ & $\begin{array}{l}-0.002 \\
(0.001)\end{array}$ \\
\hline $\begin{array}{l}\text { Implied IV (\$1000 } \\
\text { income increase) }\end{array}$ & -0.0050 & -0.0039 & -0.0031 & -0.0028 & -0.0042 & -0.0026 & -0.0034 & -0.0050 & - & -0.0014 \\
\hline Sample Mean & 0.130 & 0.130 & 0.119 & 0.119 & 0.109 & 0.170 & 0.120 & 0.132 & 0.106 & 0.143 \\
\hline $\begin{array}{l}\text { Includes time-varying } \\
\text { State controls }\end{array}$ & No & Yes & No & Yes & Yes & Yes & Yes & Yes & Yes & Yes \\
\hline \multicolumn{11}{|c|}{$\begin{array}{l}\text { Notes: Coefficients from OLS models are reported. Each cell represents the effect of a } 10 \% \text { increase in the minimum wage relative to the median wage (see text). Standard errors are adjusted for } \\
\text { arbitrary correlation in the errors across observations within each state, and reported in parentheses. All specifications control state and year of pregnancy fixed effects. Models also include the } \\
\text { following individual-specific covariates: indicators for age, race, ethnicity, marital status, and educational attainment; and the following state-specific covariates: employment-to-population ratio, } \\
\text { unemployment rate, mean wage rate for males, mean wage rate for females, indicator for state EITC, indicator for refundable state EITC, state EITC as a } \% \text { of federal EITC, indicator for AFDC } \\
\text { waiver, indicator for TANF, fraction of pregnant women eligible for Medicaid, and the mean outcome rate among married college-educated mothers ages } 25-39 \text {. Sample sizes range from } 10.3 \\
\text { million to } 45.3 \text { million observations. See Appendix A1 for full results for these covariates. Asterisks denote statistical significance as follows: } * * * \text { p-value } \leq 0.01 ; * * 0.01<\text { p-value } \leq 0.05 ; * 0.05 \\
<\text { p-value } \leq 0.10 \text {. }\end{array}$} \\
\hline
\end{tabular}


Table 5

Effect of the Relative Minimum Wage on Prenatal Inputs

\begin{tabular}{|c|c|c|c|c|c|c|c|c|c|c|}
\hline \multirow[b]{3}{*}{ Prenatal Care Visits $<5$} & \multirow{2}{*}{$\begin{array}{c}\text { Less than High } \\
\text { School }\end{array}$} & \multirow{2}{*}{$\begin{array}{l}\text { Less than High } \\
\text { School } \\
\end{array}$} & \multirow{2}{*}{$\begin{array}{l}\text { High } \\
\text { School } \\
\end{array}$} & \multirow{2}{*}{$\begin{array}{l}\text { High } \\
\text { School } \\
\end{array}$} & \multicolumn{6}{|c|}{ High School or Below } \\
\hline & & & & & White & Non-White & Age 18-29 & Age 30-39 & Married & Not Married \\
\hline & & & & & & & & & & \\
\hline Minimum wage & $\begin{array}{c}-0.0153^{* * * *} \\
(0.004)\end{array}$ & $\begin{array}{c}-0.014 * * * \\
(0.004)\end{array}$ & $\begin{array}{c}-0.0056^{* *} \\
(0.003)\end{array}$ & $\begin{array}{l}-0.0053 * * * \\
(0.002)\end{array}$ & $\begin{array}{l}-0.0133 * * * \\
(0.004)\end{array}$ & $\begin{array}{l}-0.0002 \\
(0.002)\end{array}$ & $\begin{array}{c}-0.009 * * * \\
(0.003)\end{array}$ & $\begin{array}{l}-0.0129 * * * \\
(0.004)\end{array}$ & $\begin{array}{l}-0.0095 * * * \\
(0.003)\end{array}$ & $\begin{array}{c}-0.0092 * * \\
(0.004)\end{array}$ \\
\hline Implied IV & -0.0180 & -0.0164 & -0.0040 & -0.0038 & -0.0114 & -0.0002 & -0.0081 & -0.0142 & - & -0.0065 \\
\hline Sample mean & 0.104 & 0.104 & 0.050 & 0.050 & 0.058 & 0.108 & 0.072 & 0.062 & 0.047 & 0.096 \\
\hline \multicolumn{11}{|l|}{$\begin{array}{l}\text { Months delayed prenatal } \\
\text { care }\end{array}$} \\
\hline Minimum wage & $\begin{array}{c}-0.20 * * * \\
(0.060)\end{array}$ & $\begin{array}{c}-0.18 * * * \\
(0.060)\end{array}$ & $\begin{array}{c}-0.04 \\
(0.040)\end{array}$ & $\begin{array}{c}-0.05 \\
(0.040)\end{array}$ & $\begin{array}{c}-0.16^{* * *} \\
(0.050)\end{array}$ & $\begin{array}{c}0.04 \\
(0.050)\end{array}$ & $\begin{array}{l}-0.10^{*} \\
(0.050)\end{array}$ & $\begin{array}{c}-0.15 * * * \\
(0.050)\end{array}$ & $\begin{array}{l}-0.12 * * \\
(0.050)\end{array}$ & $\begin{array}{c}-0.09 \\
(0.060)\end{array}$ \\
\hline Implied IV & -0.23 & -0.21 & -0.03 & -0.04 & -0.14 & 0.04 & -0.09 & -0.17 & - & -0.06 \\
\hline Sample Mean & 3.427 & 3.427 & 2.842 & 2.842 & 2.966 & 3.365 & 3.106 & 2.886 & 2.774 & 3.381 \\
\hline \multicolumn{11}{|l|}{ Any Prenatal Smoking } \\
\hline Minimum wage & $\begin{array}{c}-0.0093 * * \\
(0.004)\end{array}$ & $\begin{array}{l}-0.0090^{* * *} \\
(0.003)\end{array}$ & $\begin{array}{l}-0.0067 \\
(0.006)\end{array}$ & $\begin{array}{l}-0.0054 \\
(0.004)\end{array}$ & $\begin{array}{l}-0.0037 \\
(0.004)\end{array}$ & $\begin{array}{l}-0.0138^{* * *} \\
(0.003)\end{array}$ & $\begin{array}{l}-0.006^{*} \\
(0.003)\end{array}$ & $\begin{array}{l}-0.0015 \\
(0.003)\end{array}$ & $\begin{array}{l}-0.0077 * * * \\
(0.002)\end{array}$ & $\begin{array}{l}-0.0095 * * \\
(0.004)\end{array}$ \\
\hline Implied IV & -0.0109 & -0.0106 & -0.0048 & -0.0038 & -0.0032 & -0.0128 & -0.0054 & -0.0017 & - & -0.0068 \\
\hline Sample Mean & 0.226 & 0.226 & 0.171 & 0.171 & 0.208 & 0.134 & 0.197 & 0.167 & 0.15 & 0.23 \\
\hline \multicolumn{11}{|l|}{ Smoking >5 Cigs. Daily } \\
\hline Minimum wage & $\begin{array}{l}-0.0068 \\
(0.005)\end{array}$ & $\begin{array}{c}-0.0082 * * \\
(0.004)\end{array}$ & $\begin{array}{l}-0.007 \\
(0.005)\end{array}$ & $\begin{array}{l}-0.0066 \\
(0.004)\end{array}$ & $\begin{array}{l}-0.0052 \\
(0.004)\end{array}$ & $\begin{array}{c}-0.0104 * * * \\
(0.003)\end{array}$ & $\begin{array}{c}-0.007 * * \\
(0.003)\end{array}$ & $\begin{array}{l}-0.0026 \\
(0.004)\end{array}$ & $\begin{array}{c}-0.0068^{* * *} \\
(0.002)\end{array}$ & $\begin{array}{c}-0.0097 * * \\
(0.005)\end{array}$ \\
\hline Implied IV & -0.0080 & -0.0096 & -0.0050 & -0.0047 & -0.0045 & -0.0097 & -0.0063 & -0.0029 & - & -0.0069 \\
\hline Sample Mean & 0.160 & 0.160 & 0.117 & 0.117 & 0.151 & 0.071 & 0.134 & 0.122 & 0.11 & 0.15 \\
\hline $\begin{array}{l}\text { Includes time-varying } \\
\text { State controls }\end{array}$ & No & Yes & No & Yes & Yes & Yes & Yes & Yes & Yes & Yes \\
\hline $\begin{array}{l}\text { Notes: Coefficients from OL } \\
\text { arbitrary correlation in the er } \\
\text { following individual-specific } \\
\text { unemployment rate, mean w } \\
\text { waiver, indicator for TANF, } \\
\text { million to } 45.3 \text { million obser }\end{array}$ & $\begin{array}{l}\text { odels are rep } \\
\text { across obser } \\
\text { variates: indi } \\
\text { rate for male } \\
\text { ction of pregn } \\
\text { lons. See Ap }\end{array}$ & $\begin{array}{l}\text { d. Each cell re } \\
\text { ons within eac } \\
\text { s for age, race } \\
\text { ean wage rate } \\
\text { women eligibl } \\
\text { ix A1 for full }\end{array}$ & $\begin{array}{l}\text { ents the e } \\
\text { e, and re } \\
\text { icity, ma } \\
\text { males, in } \\
\text { Medicaid } \\
\text { s for thes }\end{array}$ & $\begin{array}{l}\text { a } 10 \% \text { in } \\
\text { in parenth } \\
\text { atus, and } \\
r \text { for state } \\
\text { he mean } \\
\text { iriates. A }\end{array}$ & $\begin{array}{l}\text { in the } m \\
\text { All specif } \\
\text { ional atta } \\
\text { indicator } \\
\text { e rate am } \\
\text { s denote s }\end{array}$ & $\begin{array}{l}\text { wage rela } \\
\text { control s } \\
\text { and the ff } \\
\text { undable st } \\
\text { arried colle } \\
\text { al significa }\end{array}$ & $\begin{array}{l}\text { the medi } \\
\text { lyear of } \\
\text { g state-s } \\
\text { C, state }\end{array}$ & $\begin{array}{l}\text { e (see text } \\
\text { cy fixed e } \\
\text { covariates: } \\
\text { a } \% \text { of fe } \\
\text { ges } 25-39 \text {. } \\
\text { value } \leq 0 \text {. }\end{array}$ & $\begin{array}{l}\text { ndard errors } \\
\text { s. Models a } \\
\text { loyment-to- } \\
\text { EITC, indic } \\
\text { ple sizes ra } \\
0.01<\text { p-v }\end{array}$ & $\begin{array}{l}\text { adjusted for } \\
\text { include the } \\
\text { ulation ratio, } \\
\text { for AFDC } \\
\text { from } 10.3 \\
\leq 0.05\end{array}$ \\
\hline
\end{tabular}


Table 6

Cumulative and Lead Effects of the Relative Minimum Wage on Infant Health \& Prenatal Inputs

Low-educated Mothers (High school or below)

\begin{tabular}{|c|c|c|c|c|c|c|c|c|c|}
\hline Outcome & Birth weight & $\begin{array}{l}\text { Low birth } \\
\text { weight }\end{array}$ & Fetal growth & $\begin{array}{l}\text { Gestation } \\
\text { (weeks) }\end{array}$ & Preterm birth & $\begin{array}{c}\text { Months } \\
\text { delayed } \\
\text { prenatal care }\end{array}$ & $\begin{array}{c}\text { Prenatal Care } \\
\text { Visits }<5\end{array}$ & $\begin{array}{l}\text { Any prenatal } \\
\text { smoking }\end{array}$ & $\begin{array}{c}\text { Smoking } \\
<5 \text { cigs. } \\
\text { daily }\end{array}$ \\
\hline \multirow{2}{*}{$\begin{array}{l}\text { Panel A } \\
\text { MW (pregnancy) }\end{array}$} & & & & & & & & & \\
\hline & $\begin{array}{c}13.56^{* * * *} \\
(2.25)\end{array}$ & $\begin{array}{c}-0.0025^{* * *} \\
(0.001)\end{array}$ & $\begin{array}{c}0.20^{* * *} \\
(0.04)\end{array}$ & $\begin{array}{c}0.10^{* * * *} \\
(0.02)\end{array}$ & $\begin{array}{c}-0.0038^{* *} \\
(0.001)\end{array}$ & $\begin{array}{l}-0.11^{* *} \\
(0.05)\end{array}$ & $\begin{array}{c}-0.0097 * * * \\
(0.003)\end{array}$ & $\begin{array}{c}-0.0055^{*} \\
(0.003)\end{array}$ & $\begin{array}{c}-0.0062 * \\
(0.004)\end{array}$ \\
\hline \multirow{2}{*}{$\begin{array}{l}\text { Panel B } \\
\text { Avg. MW (pregnancy + past } 2 \text { yrs.) }\end{array}$} & & & & & & & & & \\
\hline & $\begin{array}{c}14.08^{* * * *} \\
(3.12)\end{array}$ & $\begin{array}{l}-0.0034 * * * \\
(0.001)\end{array}$ & $\begin{array}{c}0.23 * * * \\
(0.06)\end{array}$ & $\begin{array}{c}0.12 * * * \\
(0.03)\end{array}$ & $\begin{array}{l}-0.0055^{* * *} \\
(0.002)\end{array}$ & $\begin{array}{c}-0.16^{* * * *} \\
(0.06)\end{array}$ & $\begin{array}{c}-0.0141 * * * \\
(0.005)\end{array}$ & $\begin{array}{c}-0.0085^{*} \\
(0.004)\end{array}$ & $\begin{array}{c}-0.0094 * \\
(0.005)\end{array}$ \\
\hline \multirow{2}{*}{$\begin{array}{l}\text { Panel C } \\
\text { Avg. MW (pregnancy + past } 2 \text { yrs. }+3 \\
\text { years of leads) }\end{array}$} & & & & & & & & & \\
\hline & $\begin{array}{c}11.75^{* * * *} \\
(3.07)\end{array}$ & $\begin{array}{c}-0.0030 * * * \\
(0.001)\end{array}$ & $\begin{array}{c}0.20^{* * *} \\
(0.05)\end{array}$ & $\begin{array}{c}0.10^{* * * *} \\
(0.02)\end{array}$ & $\begin{array}{c}-0.0042 * * \\
(0.002)\end{array}$ & $\begin{array}{c}-0.12 * * * \\
(0.03)\end{array}$ & $\begin{array}{c}-0.0110^{* * * *} \\
(0.003)\end{array}$ & $\begin{array}{c}-0.0106^{* *} \\
(0.004)\end{array}$ & $\begin{array}{c}-0.0109^{*} \\
(0.006)\end{array}$ \\
\hline MW (one-year lead) & $\begin{array}{c}0.14 \\
(1.35)\end{array}$ & $\begin{array}{l}0.0004 \\
(0.001)\end{array}$ & $\begin{array}{c}0.01 \\
(0.03)\end{array}$ & $\begin{array}{l}-0.003 \\
(0.01)\end{array}$ & $\begin{array}{l}0.0006 \\
(0.001)\end{array}$ & $\begin{array}{c}0.01 \\
(0.02)\end{array}$ & $\begin{array}{l}0.0028 \\
(0.002)\end{array}$ & $\begin{array}{l}0.0001 \\
(0.002)\end{array}$ & $\begin{array}{l}0.0004 \\
(0.002)\end{array}$ \\
\hline MW (two-year lead) & $\begin{array}{c}1.36 \\
(1.22)\end{array}$ & $\begin{array}{l}-0.0008 \\
(0.001)\end{array}$ & $\begin{array}{l}0.005 \\
(0.02)\end{array}$ & $\begin{array}{c}0.03 * * * \\
(0.01)\end{array}$ & $\begin{array}{c}-0.0021^{* * *} \\
(0.001)\end{array}$ & $\begin{array}{c}-0.05 * * \\
(0.03)\end{array}$ & $\begin{array}{c}-0.0045^{* *} \\
(0.002)\end{array}$ & $\begin{array}{l}0.0017 \\
(0.002)\end{array}$ & $\begin{array}{l}0.0023 \\
(0.002)\end{array}$ \\
\hline MW (three-year lead) & $\begin{array}{c}3.69 * * * \\
(1.23)\end{array}$ & $\begin{array}{c}-0.0011^{* *} \\
(0.0004)\end{array}$ & $\begin{array}{l}0.07 * * \\
(0.03)\end{array}$ & $\begin{array}{c}0.03 * * \\
(0.01)\end{array}$ & $\begin{array}{c}-0.0028^{* * *} \\
(0.001)\end{array}$ & $\begin{array}{l}-0.09^{* *} \\
(0.04)\end{array}$ & $\begin{array}{c}-0.008^{* *} \\
(0.004)\end{array}$ & $\begin{array}{l}0.0022 \\
(0.002)\end{array}$ & $\begin{array}{l}-0.0013 \\
(0.003)\end{array}$ \\
\hline Sample Mean & 3269.1 & 0.082 & 82.051 & 38.8 & 0.123 & 10.8 & 0.727 & 0.190 & 0.132 \\
\hline
\end{tabular}


Figure 1. Changes in State Minimum Wages over Time

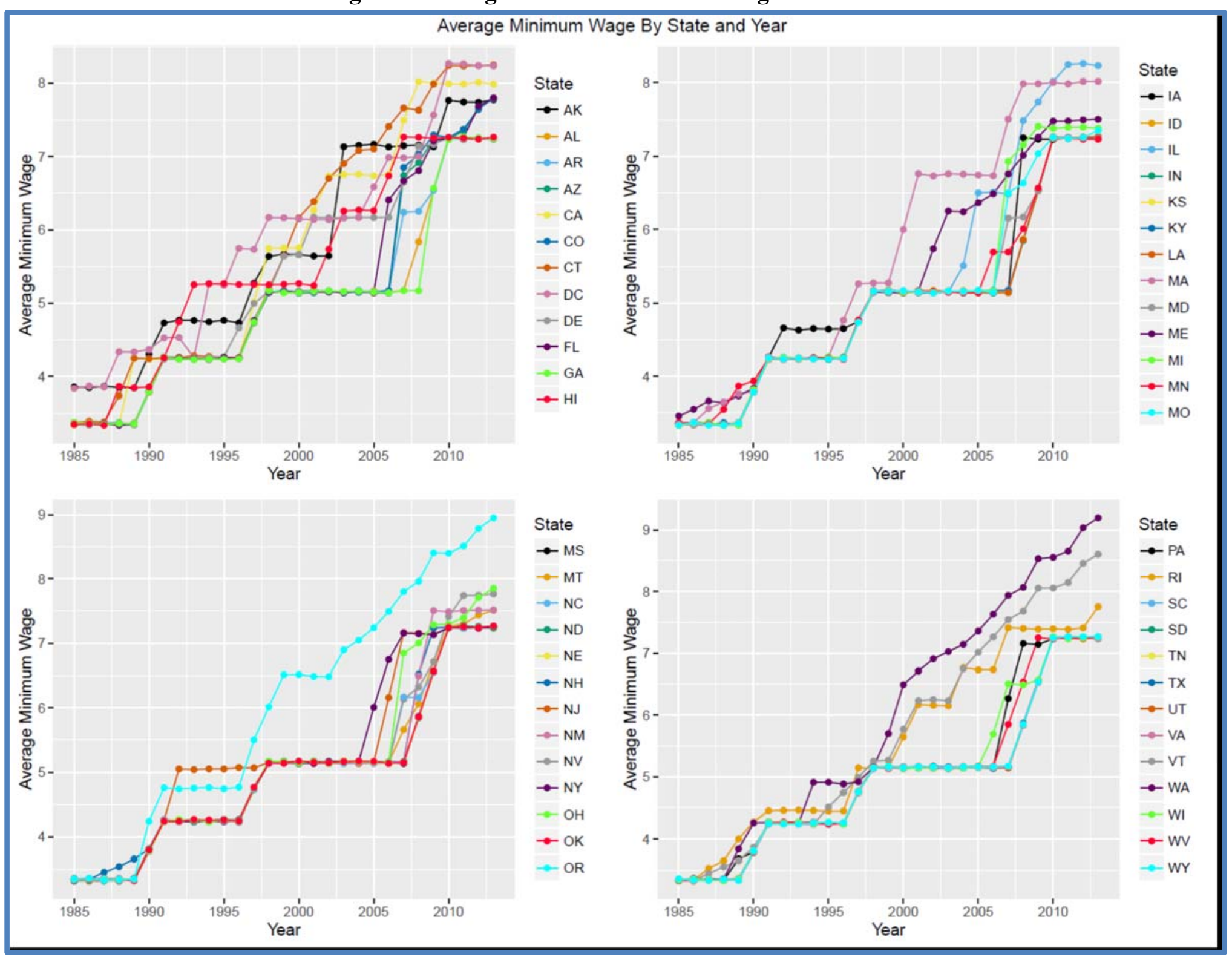




\section{Appendix Table A1}

Effects of a \$1 increase in the Minimum Wage on Earnings, Household Income, and Hourly Wage Current Population Survey 1988-2012

\begin{tabular}{|c|c|c|c|c|c|c|c|c|c|}
\hline \multirow[t]{2}{*}{ Sample } & \multirow{2}{*}{$\begin{array}{c}\text { High School } \\
\text { or Below } \\
\text { Ages 18-39 } \\
\end{array}$} & \multirow{2}{*}{$\begin{array}{c}\text { Less than } \\
\text { High School } \\
\text { Ages 18-39 } \\
\end{array}$} & \multirow{2}{*}{$\begin{array}{c}\text { High School } \\
\text { Ages 18-39 }\end{array}$} & \multicolumn{6}{|c|}{ High School or Below } \\
\hline & & & & White & Non-White & Age 18-29 & Age $30-39$ & Married & Not Married \\
\hline \multicolumn{10}{|l|}{$\begin{array}{l}\text { Panel A } \\
\text { Household Income }\end{array}$} \\
\hline Minimum Wage & $\begin{array}{c}772.5268 * * \\
(301.8830)\end{array}$ & $\begin{array}{l}681.7382 * \\
(397.3814)\end{array}$ & $\begin{array}{c}1125.5127 * * * \\
(415.2587)\end{array}$ & $\begin{array}{l}933.9056^{*} \\
(491.4875)\end{array}$ & $\begin{array}{l}861.9071 * * \\
(391.0147)\end{array}$ & $\begin{array}{r}884.8692 * * \\
(414.4247)\end{array}$ & $\begin{array}{l}726.3930^{*} \\
(423.8423)\end{array}$ & $\begin{array}{c}-81.4353 \\
(389.7715)\end{array}$ & $\begin{array}{c}1123.9672 * * * \\
(376.5650)\end{array}$ \\
\hline \multicolumn{10}{|l|}{$\begin{array}{l}\text { Panel B } \\
\text { Annual Earnings }\end{array}$} \\
\hline Minimum Wage & $\begin{array}{l}525.7892 * \\
(278.7056)\end{array}$ & $\begin{array}{c}353.8639 \\
(337.1619)\end{array}$ & $\begin{array}{c}903.2696^{* *} \\
(391.0015)\end{array}$ & $\begin{array}{c}403.6355 \\
(444.9469)\end{array}$ & $\begin{array}{c}812.4176^{* *} \\
(365.5610)\end{array}$ & $\begin{array}{c}380.9442 \\
(357.0152)\end{array}$ & $\begin{array}{c}616.7163 \\
(402.2614)\end{array}$ & $\begin{array}{l}-112.5564 \\
(367.6792)\end{array}$ & $\begin{array}{c}456.9711 \\
(301.8269)\end{array}$ \\
\hline \multicolumn{10}{|l|}{$\begin{array}{l}\text { Panel C } \\
\text { Hourly Wage }\end{array}$} \\
\hline Minimum Wage & $\begin{array}{c}0.2145 * * * \\
(0.0496) \\
\end{array}$ & $\begin{array}{c}0.3091 * * * \\
(0.0974)\end{array}$ & $\begin{array}{c}0.1943 * * * \\
(0.0572) \\
\end{array}$ & $\begin{array}{c}0.2293 * * * \\
(0.0740)\end{array}$ & $\begin{array}{c}0.2414 * * * \\
(0.0666)\end{array}$ & $\begin{array}{c}0.2438 * * * \\
(0.0601) \\
\end{array}$ & $\begin{array}{l}0.2074 * * \\
(0.0813) \\
\end{array}$ & $\begin{array}{c}0.0534 \\
(0.0806) \\
\end{array}$ & $\begin{array}{c}0.3348 * * * \\
(0.0623) \\
\end{array}$ \\
\hline
\end{tabular}




\section{Appendix Table A2}

Effects of Minimum Wage on Birth Weight

\begin{tabular}{|c|c|c|c|}
\hline Covariate & $\begin{array}{l}\text { High School or } \\
\text { Below }\end{array}$ & $\begin{array}{l}\text { Less than High } \\
\text { School }\end{array}$ & High School Only \\
\hline Minimum wage & $\begin{array}{c}13.5624 * * * \\
(2.26)\end{array}$ & $\begin{array}{c}10.0023^{* * *} \\
(3.00)\end{array}$ & $\begin{array}{c}16.173 * * * \\
(2.32)\end{array}$ \\
\hline Age 19 & $\begin{array}{c}7.426 * * * \\
(1.933)\end{array}$ & $\begin{array}{l}4.322 * * \\
(1.997)\end{array}$ & $\begin{array}{l}7.45 * * * \\
(1.221)\end{array}$ \\
\hline Age 20 & $\begin{array}{c}15.004 * * * \\
(3.525)\end{array}$ & $\begin{array}{c}10.579 * * * \\
(3.468)\end{array}$ & $\begin{array}{c}14.295 * * * \\
(2.509)\end{array}$ \\
\hline Age 21 & $\begin{array}{c}22.305 * * * \\
(4.581)\end{array}$ & $\begin{array}{c}17.367 * * * \\
(4.619)\end{array}$ & $\begin{array}{c}20.878 * * * \\
(3.387)\end{array}$ \\
\hline Age 22 & $\begin{array}{c}32.182 * * * \\
(5.279)\end{array}$ & $\begin{array}{c}25.277 * * * \\
(5.898)\end{array}$ & $\begin{array}{c}30.785 * * * \\
(3.647)\end{array}$ \\
\hline Age 23 & $\begin{array}{c}38.931 * * * \\
(6.074)\end{array}$ & $\begin{array}{c}30.418 * * * \\
(6.82)\end{array}$ & $\begin{array}{c}37.331 * * * \\
(4.397)\end{array}$ \\
\hline Age 24 & $\begin{array}{c}44.569 * * * \\
(6.622)\end{array}$ & $\begin{array}{c}37.358 * * * \\
(8.306)\end{array}$ & $\begin{array}{c}41.24 * * * \\
(4.315)\end{array}$ \\
\hline Age 25 & $\begin{array}{c}49.403 * * * \\
(7.437)\end{array}$ & $\begin{array}{l}41.7 * * * \\
(9.378)\end{array}$ & $\begin{array}{c}45.474 * * * \\
(4.961)\end{array}$ \\
\hline Age 26 & $\begin{array}{c}53.083 * * * \\
(7.989)\end{array}$ & $\begin{array}{c}47.378 * * * \\
(10.203)\end{array}$ & $\begin{array}{c}47.408 * * * \\
(5.258)\end{array}$ \\
\hline Age 27 & $\begin{array}{c}56.488^{* * * *} \\
(8.378)\end{array}$ & $\begin{array}{l}51.66 * * * \\
(10.942)\end{array}$ & $\begin{array}{c}49.76 * * * \\
(5.399)\end{array}$ \\
\hline Age 28 & $\begin{array}{c}57.955^{* * *} \\
(8.628)\end{array}$ & $\begin{array}{c}55.386 * * * \\
(11.351)\end{array}$ & $\begin{array}{c}49.65 * * * \\
(5.389)\end{array}$ \\
\hline Age 29 & $\begin{array}{c}59.649 * * * \\
(9.227)\end{array}$ & $\begin{array}{c}59.809 * * * \\
(12.164)\end{array}$ & $\begin{array}{c}49.643 * * * \\
(5.664)\end{array}$ \\
\hline Age 30 & $\begin{array}{c}59.356^{* * *} \\
(9.319)\end{array}$ & $\begin{array}{c}61.482 * * * \\
(12.351)\end{array}$ & $\begin{array}{c}48.141 * * * \\
(5.544)\end{array}$ \\
\hline Age 31 & $\begin{array}{c}57.11 * * * \\
(9.775)\end{array}$ & $\begin{array}{c}61.678 * * * \\
(12.948)\end{array}$ & $\begin{array}{c}44.548 * * * \\
(5.773)\end{array}$ \\
\hline Age 32 & $\begin{array}{c}55.522 * * * \\
(9.761)\end{array}$ & $\begin{array}{c}61.501 * * * \\
(12.987)\end{array}$ & $\begin{array}{c}42.108 * * * \\
(5.532)\end{array}$ \\
\hline Age 33 & $\begin{array}{c}53.178^{* * *} \\
(10.327)\end{array}$ & $\begin{array}{c}60.139 * * * \\
(13.634)\end{array}$ & $\begin{array}{c}39.152 * * * \\
(5.918)\end{array}$ \\
\hline Age 34 & $\begin{array}{c}48.449 * * * \\
(10.85)\end{array}$ & $\begin{array}{c}60.773 * * * \\
(13.903)\end{array}$ & $\begin{array}{c}31.86 * * * \\
(6.074)\end{array}$ \\
\hline Age 35 & $\begin{array}{c}41.492 * * * \\
(11.179)\end{array}$ & $\begin{array}{c}56.278 * * * \\
(13.846)\end{array}$ & $\begin{array}{c}23.613 * * * \\
(6.353)\end{array}$ \\
\hline Age 36 & $\begin{array}{c}35.916 * * * \\
(10.938)\end{array}$ & $\begin{array}{c}52.394 * * * \\
(13.403)\end{array}$ & $\begin{array}{c}16.966 * * * \\
(5.989)\end{array}$ \\
\hline Age 37 & $29.461 * *$ & $48.053 * * *$ & 9.242 \\
\hline
\end{tabular}




\begin{tabular}{|c|c|c|c|}
\hline & $(11.131)$ & $(13.681)$ & $(6.207)$ \\
\hline \multirow[t]{2}{*}{ Age 38} & $22.666^{*}$ & $44.489 * * *$ & 0.415 \\
\hline & $(11.997)$ & $(13.642)$ & $(6.797)$ \\
\hline \multirow[t]{2}{*}{ Age 39} & $18.463^{*}$ & $37.637 * * *$ & -2.717 \\
\hline & $(10.521)$ & $(11.7)$ & $(5.844)$ \\
\hline \multirow[t]{2}{*}{ High school graduate } & $38.062 * * *$ & . & . \\
\hline & $(6.126)$ & . & . \\
\hline \multirow[t]{2}{*}{ Black } & $-193.04 * * *$ & $-167.458 * * *$ & $-202.618 * * *$ \\
\hline & $(6.535)$ & $(8.281)$ & $(5.442)$ \\
\hline \multirow[t]{2}{*}{ Other race } & $-70.499 * * *$ & $-29.653^{*}$ & $-86.561 * * *$ \\
\hline & $(17.146)$ & $(16.77)$ & $(16.691)$ \\
\hline \multirow[t]{2}{*}{ Hispanic } & $24.581 * * *$ & $69.405^{* * *}$ & $-11.833 * *$ \\
\hline & $(6.417)$ & $(6.829)$ & $(4.769)$ \\
\hline \multirow[t]{2}{*}{ Married } & $74.87 * * *$ & $65.538^{* * *}$ & $78.396^{* * *}$ \\
\hline & $(5.889)$ & $(7.407)$ & $(4.565)$ \\
\hline \multirow[t]{2}{*}{ Cigarette excise tax } & $0.074 * * *$ & $0.092 * *$ & $0.071 * * *$ \\
\hline & $(0.024)$ & $(0.034)$ & $(0.023)$ \\
\hline \multirow[t]{2}{*}{ State EITC } & -7.46 & -6.65 & -7.672 \\
\hline & $(5.88)$ & (7.699) & $(5.141)$ \\
\hline \multirow[t]{2}{*}{ State EITC Refundable } & 7.724 & $13.15^{*}$ & 5.572 \\
\hline & $(5.966)$ & $(7.785)$ & $(5.402)$ \\
\hline \multirow[t]{2}{*}{ State EITC (\% of Federal EITC) } & $0.683 * *$ & $0.794 * *$ & $0.594 * *$ \\
\hline & $(0.293)$ & $(0.371)$ & $(0.26)$ \\
\hline \multirow[t]{2}{*}{ AFDC Waiver } & -2.743 & 1.204 & $-5.324 * *$ \\
\hline & $(2.72)$ & $(2.877)$ & $(2.478)$ \\
\hline \multirow[t]{2}{*}{ TANF Implementation } & $-23.734 * * *$ & $-23.092 * * *$ & $-24.468 * * *$ \\
\hline & $(4.801)$ & $(4.679)$ & $(5.031)$ \\
\hline \multirow[t]{2}{*}{ Medicaid eligibility for pregnant women } & 4.345 & 26.14 & -2.187 \\
\hline & $(20.431)$ & $(28.167)$ & $(18.833)$ \\
\hline \multirow[t]{2}{*}{$\begin{array}{l}\text { Mean birth weight in state among } \\
\text { college-educated married mothers }\end{array}$} & -0.191 & -0.148 & -0.208 \\
\hline & $(0.162)$ & $(0.185)$ & $(0.153)$ \\
\hline \multirow[t]{2}{*}{ Constant } & $3811.57 * * *$ & $3643.022 * * *$ & $3916.802 * * *$ \\
\hline & $(563.364)$ & $(640.482)$ & $(528.711)$ \\
\hline State fixed effects included & $\mathrm{Y}$ & $\mathrm{Y}$ & Y \\
\hline Year fixed effects included & $\mathrm{Y}$ & $\mathrm{Y}$ & $\mathrm{Y}$ \\
\hline
\end{tabular}


Appendix Table A3

Effect of the Relative Minimum Wage on Number of Prenatal Care Visits

\begin{tabular}{|c|c|c|c|c|c|c|c|c|c|c|}
\hline & \multirow{2}{*}{$\begin{array}{l}\text { Less than } \\
\text { High School }\end{array}$} & \multirow{2}{*}{$\begin{array}{l}\text { Less than } \\
\text { High School }\end{array}$} & \multirow{2}{*}{$\begin{array}{l}\text { High } \\
\text { School }\end{array}$} & \multirow{2}{*}{$\begin{array}{l}\text { High } \\
\text { School }\end{array}$} & \multicolumn{2}{|c|}{ High School or Below } & \multirow[b]{2}{*}{ Age 18-29 } & \multirow[b]{2}{*}{ Age $30-39$} & \multirow[b]{2}{*}{ Married } & \multirow[b]{2}{*}{ Not Married } \\
\hline & & & & & White & Non-White & & & & \\
\hline Prenatal Care Visits $<5$ & & & & & & & & & & \\
\hline Minimum wage & $\begin{array}{c}0.49 * * * \\
(0.16)\end{array}$ & $\begin{array}{c}0.46^{* * *} \\
(0.16)\end{array}$ & $\begin{array}{c}0.14 * * \\
(0.07)\end{array}$ & $\begin{array}{c}0.13 * * \\
(0.06)\end{array}$ & $\begin{array}{c}0.39 * * * \\
(0.14)\end{array}$ & $\begin{array}{l}-0.06 \\
(0.07)\end{array}$ & $\begin{array}{c}0.27 * * \\
(0.12)\end{array}$ & $\begin{array}{c}0.33^{* * *} \\
(0.11)\end{array}$ & $\begin{array}{c}0.27 * * \\
(0.11)\end{array}$ & $\begin{array}{l}0.26^{*} \\
(0.13)\end{array}$ \\
\hline $\begin{array}{r}\text { Implied IV estimate } \\
\text { (\$1000 income } \\
\text { increase) }\end{array}$ & 0.58 & 0.54 & 0.10 & 0.09 & 0.33 & -0.06 & 0.24 & 0.36 & - & 0.19 \\
\hline Sample mean & 10.0 & 10.0 & 11.2 & 11.2 & 11.0 & 10.0 & 10.7 & 11.0 & 11.3 & 10.2 \\
\hline
\end{tabular}

Notes: See Table 5. Sample sizes range from 9,822,354 to 33,941,949. 
Appendix Table 4

Alternate Measures of Minimum Wage

\begin{tabular}{|c|c|c|c|c|c|c|c|c|c|c|}
\hline \multirow[t]{2}{*}{ Sample } & \multirow{2}{*}{$\begin{array}{l}\text { Less than } \\
\text { High School }\end{array}$} & \multirow[t]{2}{*}{$\begin{array}{l}\text { Less than } \\
\text { High School }\end{array}$} & \multirow[t]{2}{*}{$\begin{array}{l}\text { High } \\
\text { School }\end{array}$} & \multirow[t]{2}{*}{$\begin{array}{l}\text { High } \\
\text { School }\end{array}$} & \multicolumn{6}{|c|}{ High School or Below } \\
\hline & & & & & White & Non-White & Age $18-29$ & Age $30-39$ & Married & Not Married \\
\hline \multicolumn{11}{|l|}{ Birth Weight } \\
\hline Minimum wage & $\begin{array}{l}7.1 * * \\
(3.2)\end{array}$ & $\begin{array}{c}7.0 * * * \\
(2.2)\end{array}$ & $\begin{array}{c}14.5^{* * *} \\
(1.8)\end{array}$ & $\begin{array}{c}13.3 * * * \\
(1.9)\end{array}$ & $\begin{array}{c}9.6 * * * \\
(1.6)\end{array}$ & $\begin{array}{c}16.5^{* * * *} \\
(2.9)\end{array}$ & $\begin{array}{c}12.2 * * * \\
(1.9)\end{array}$ & $\begin{array}{l}4.3^{*} \\
(2.5)\end{array}$ & $\begin{array}{c}9.5^{* * * *} \\
(1.6)\end{array}$ & $\begin{array}{c}10.1^{* * * *} \\
(2.0)\end{array}$ \\
\hline Minimum wage (2012\$) & $\begin{array}{l}6.5^{* *} \\
(2.5)\end{array}$ & $\begin{array}{c}6.4 * * * \\
(1.7)\end{array}$ & $\begin{array}{c}11.8^{* * *} * \\
(1.5)\end{array}$ & $\begin{array}{c}10.8^{* * * *} \\
(1.4)\end{array}$ & $\begin{array}{c}8.3^{* * * *} \\
(1.2)\end{array}$ & $\begin{array}{c}12.6^{* * * *} \\
(2.2)\end{array}$ & $\begin{array}{c}10.1 * * * \\
(1.5)\end{array}$ & $\begin{array}{l}4.3 * * \\
(2.0)\end{array}$ & $\begin{array}{c}8.3 * * * \\
(1.3)\end{array}$ & $\begin{array}{c}8.4 * * * \\
(1.7)\end{array}$ \\
\hline \multicolumn{11}{|l|}{ Low Birth Weight } \\
\hline Minimum wage & $\begin{array}{l}-0.001 \\
(0.001)\end{array}$ & $\begin{array}{c}-0.001 \\
(0.001)\end{array}$ & $\begin{array}{c}-0.003 * * * \\
(0.001)\end{array}$ & $\begin{array}{c}-0.002 * * * \\
(0.001)\end{array}$ & $\begin{array}{c}-0.001 * * \\
(0.001)\end{array}$ & $\begin{array}{c}-0.004 * * * \\
(0.001)\end{array}$ & $\begin{array}{c}-0.002 * * * \\
(0.001)\end{array}$ & $\begin{array}{c}-0.001 \\
(0.001)\end{array}$ & $\begin{array}{c}-0.001 * * \\
(0.001)\end{array}$ & $\begin{array}{c}-0.002 * * \\
(0.001)\end{array}$ \\
\hline Minimum wage (2012\$) & $\begin{array}{l}-0.001 \\
(0.001)\end{array}$ & $\begin{array}{l}-0.001 \\
(0.001)\end{array}$ & $\begin{array}{c}-0.002 * * * \\
(0.000)\end{array}$ & $\begin{array}{c}-0.002 * * * \\
(0.000)\end{array}$ & $\begin{array}{c}-0.001 * * \\
(0.000)\end{array}$ & $\begin{array}{c}-0.003^{* * *} \\
(0.001)\end{array}$ & $\begin{array}{c}-0.001 * * * \\
(0.000)\end{array}$ & $\begin{array}{l}-0.001 \\
(0.001)\end{array}$ & $\begin{array}{c}-0.001 * * \\
(0.000)\end{array}$ & $\begin{array}{c}-0.001 * * \\
(0.001)\end{array}$ \\
\hline \multicolumn{11}{|l|}{ Fetal Growth } \\
\hline Minimum wage & $\begin{array}{c}0.101^{* * *} \\
(0.036)\end{array}$ & $\begin{array}{c}0.096 * * * \\
(0.029)\end{array}$ & $\begin{array}{c}0.216^{* * *} \\
(0.026)\end{array}$ & $\begin{array}{c}0.196 * * * \\
(0.030)\end{array}$ & $\begin{array}{c}0.109 * * * \\
(0.025)\end{array}$ & $\begin{array}{c}0.277 * * * \\
(0.053)\end{array}$ & $\begin{array}{c}0.175 * * * \\
(0.028)\end{array}$ & $\begin{array}{c}0.046 \\
(0.052)\end{array}$ & $\begin{array}{c}0.111 * * * \\
(0.022)\end{array}$ & $\begin{array}{c}0.156^{* * *} * \\
(0.032)\end{array}$ \\
\hline Minimum wage (2012\$) & $\begin{array}{c}0.091^{* * *} \\
(0.026)\end{array}$ & $\begin{array}{c}0.087 * * * \\
(0.022)\end{array}$ & $\begin{array}{c}0.169^{* * *} \\
(0.022)\end{array}$ & $\begin{array}{c}0.153 * * * \\
(0.022)\end{array}$ & $\begin{array}{c}0.096^{* * *} \\
(0.020)\end{array}$ & $\begin{array}{c}0.203 * * * \\
(0.041)\end{array}$ & $\begin{array}{c}0.142^{* * *} \\
(0.022)\end{array}$ & $\begin{array}{c}0.043 \\
(0.041)\end{array}$ & $\begin{array}{c}0.097 * * * \\
(0.017)\end{array}$ & $\begin{array}{c}0.126 * * * \\
(0.027)\end{array}$ \\
\hline \multicolumn{11}{|l|}{ Gestation Weeks } \\
\hline Minimum wage & $\begin{array}{c}0.082 * * * \\
(0.019)\end{array}$ & $\begin{array}{c}0.079 * * * \\
(0.021)\end{array}$ & $\begin{array}{c}0.093 * * * \\
(0.014)\end{array}$ & $\begin{array}{c}0.088^{* * * *} \\
(0.015)\end{array}$ & $\begin{array}{c}0.090^{* * *} \\
(0.018)\end{array}$ & $\begin{array}{c}0.089 * * * \\
(0.019)\end{array}$ & $\begin{array}{c}0.089 * * * \\
(0.017)\end{array}$ & $\begin{array}{c}0.069 * * * \\
(0.017)\end{array}$ & $\begin{array}{c}0.095^{* * *} \\
(0.017)\end{array}$ & $\begin{array}{c}0.072 * * * \\
(0.017)\end{array}$ \\
\hline Minimum wage (2012\$) & $\begin{array}{c}0.066^{* * * *} \\
(0.015)\end{array}$ & $\begin{array}{c}0.063 * * * \\
(0.015)\end{array}$ & $\begin{array}{c}0.074 * * * \\
(0.012)\end{array}$ & $\begin{array}{c}0.070 * * * \\
(0.011)\end{array}$ & $\begin{array}{c}0.072 * * * \\
(0.012)\end{array}$ & $\begin{array}{c}0.069 * * * \\
(0.015)\end{array}$ & $\begin{array}{c}0.071 * * * \\
(0.013)\end{array}$ & $\begin{array}{c}0.057 * * * \\
(0.012)\end{array}$ & $\begin{array}{c}0.076^{* * *} * \\
(0.012)\end{array}$ & $\begin{array}{c}0.058 * * * \\
(0.013)\end{array}$ \\
\hline \multicolumn{11}{|l|}{ Preterm ( $<37$ Weeks) } \\
\hline Minimum wage & $\begin{array}{c}-0.003 * * \\
(0.001)\end{array}$ & $\begin{array}{c}-0.002 \\
(0.001)\end{array}$ & $\begin{array}{c}-0.003 * * * \\
(0.001)\end{array}$ & $\begin{array}{c}-0.003 * * \\
(0.001)\end{array}$ & $\begin{array}{c}-0.004 * * \\
(0.002)\end{array}$ & $\begin{array}{l}-0.002 \\
(0.001)\end{array}$ & $\begin{array}{c}-0.003 * * \\
(0.001)\end{array}$ & $\begin{array}{c}-0.003 * \\
(0.002)\end{array}$ & $\begin{array}{c}-0.004 * * * \\
(0.001)\end{array}$ & $\begin{array}{c}-0.001 \\
(0.001)\end{array}$ \\
\hline Minimum wage (2012\$) & $\begin{array}{c}-0.002 * * \\
(0.001)\end{array}$ & $\begin{array}{l}-0.002 \\
(0.001)\end{array}$ & $\begin{array}{c}-0.002 * * * \\
(0.001)\end{array}$ & $\begin{array}{c}-0.002 * * \\
(0.001)\end{array}$ & $\begin{array}{c}-0.003 * * \\
(0.001)\end{array}$ & $\begin{array}{l}-0.001 \\
(0.001)\end{array}$ & $\begin{array}{c}-0.002 * * \\
(0.001)\end{array}$ & $\begin{array}{c}-0.002^{* *} \\
(0.001)\end{array}$ & $\begin{array}{c}-0.003 * * * \\
(0.001)\end{array}$ & $\begin{array}{c}-0.001 \\
(0.001)\end{array}$ \\
\hline \multicolumn{11}{|l|}{$\begin{array}{l}\text { Month Delayed } \\
\text { Prenatal Care }\end{array}$} \\
\hline Minimum wage & $\begin{array}{c}-0.187 * * * \\
(0.053)\end{array}$ & $\begin{array}{c}-0.171^{* * *} \\
(0.051)\end{array}$ & $\begin{array}{l}-0.056 \\
(0.045)\end{array}$ & $\begin{array}{l}-0.056 \\
(0.043)\end{array}$ & $\begin{array}{c}-0.151 * * * \\
(0.048)\end{array}$ & $\begin{array}{c}0.032 \\
(0.055)\end{array}$ & $\begin{array}{c}-0.103 * * \\
(0.049)\end{array}$ & $\begin{array}{c}-0.147 * * * \\
(0.046)\end{array}$ & $\begin{array}{c}-0.120 * * * \\
(0.042)\end{array}$ & $\begin{array}{l}-0.085 \\
(0.053)\end{array}$ \\
\hline Minimum wage (2012\$) & $\begin{array}{c}-0.145^{* * *} \\
(0.037)\end{array}$ & $\begin{array}{c}-0.130 * * * \\
(0.036)\end{array}$ & $\begin{array}{l}-0.047 \\
(0.034)\end{array}$ & $\begin{array}{l}-0.047 \\
(0.033)\end{array}$ & $\begin{array}{c}-0.115^{* * * *} \\
(0.033)\end{array}$ & $\begin{array}{c}0.020 \\
(0.043)\end{array}$ & $\begin{array}{c}-0.080^{* *} \\
(0.036)\end{array}$ & $\begin{array}{c}-0.113 * * * \\
(0.033)\end{array}$ & $\begin{array}{c}-0.091 * * * \\
(0.029)\end{array}$ & $\begin{array}{l}-0.069^{*} \\
(0.041)\end{array}$ \\
\hline \multicolumn{11}{|l|}{ Prenatal Care Visits $<5$} \\
\hline Minimum wage & $\begin{array}{c}-0.012 * * * \\
(0.003)\end{array}$ & $\begin{array}{c}-0.011^{* * * *} \\
(0.004)\end{array}$ & $\begin{array}{c}-0.005^{* * *} \\
(0.002)\end{array}$ & $\begin{array}{c}-0.005^{* * *} * \\
(0.002)\end{array}$ & $\begin{array}{c}-0.011 * * * \\
(0.004)\end{array}$ & $\begin{array}{c}0.000 \\
(0.002)\end{array}$ & $\begin{array}{c}-0.007 * * \\
(0.003)\end{array}$ & $\begin{array}{c}-0.011 * * * \\
(0.003)\end{array}$ & $\begin{array}{c}-0.008 * * * \\
(0.003)\end{array}$ & $\begin{array}{c}-0.007 * * \\
(0.003)\end{array}$ \\
\hline Minimum wage (2012\$) & $\begin{array}{c}-0.008^{* * *} \\
(0.002)\end{array}$ & $\begin{array}{c}-0.008 * * * \\
(0.002)\end{array}$ & $\begin{array}{c}-0.004 * * * \\
(0.001)\end{array}$ & $\begin{array}{c}-0.004 * * * \\
(0.001)\end{array}$ & $\begin{array}{c}-0.008 * * * \\
(0.002)\end{array}$ & $\begin{array}{c}0.000 \\
(0.002)\end{array}$ & $\begin{array}{c}-0.005^{* * *} \\
(0.002)\end{array}$ & $\begin{array}{c}-0.008^{* * *} \\
(0.002)\end{array}$ & $\begin{array}{c}-0.006^{* * * *} \\
(0.002)\end{array}$ & $\begin{array}{c}-0.005 * * \\
(0.002)\end{array}$ \\
\hline
\end{tabular}




\begin{tabular}{|c|c|c|c|c|c|c|c|c|c|c|}
\hline \multicolumn{11}{|l|}{ Any Prenatal Smoking } \\
\hline Minimum wage & $\begin{array}{c}-0.010 * * * \\
(0.003)\end{array}$ & $\begin{array}{l}-0.010 * * * \\
(0.002)\end{array}$ & $\begin{array}{c}-0.011 * * \\
(0.005)\end{array}$ & $\begin{array}{c}-0.011 * * * \\
(0.004)\end{array}$ & $\begin{array}{c}-0.009 * * \\
(0.003)\end{array}$ & $\begin{array}{c}-0.013 * * * \\
(0.002)\end{array}$ & $\begin{array}{c}-0.010^{* * * *} \\
(0.003)\end{array}$ & $\begin{array}{c}-0.007 * * \\
(0.003)\end{array}$ & $\begin{array}{c}-0.011 * * * \\
(0.002)\end{array}$ & $\begin{array}{c}-0.014 * * * \\
(0.004)\end{array}$ \\
\hline Minimum wage (2012\$) & $\begin{array}{c}-0.009 * * * \\
(0.002)\end{array}$ & $\begin{array}{c}-0.009 * * * \\
(0.002)\end{array}$ & $\begin{array}{c}-0.009 * * \\
(0.004)\end{array}$ & $\begin{array}{c}-0.009 * * * \\
(0.003)\end{array}$ & $\begin{array}{c}-0.008 * * * \\
(0.003)\end{array}$ & $\begin{array}{c}-0.010^{* * *} \\
(0.002)\end{array}$ & $\begin{array}{c}-0.008 * * * \\
(0.002)\end{array}$ & $\begin{array}{c}-0.006^{* *} \\
(0.003)\end{array}$ & $\begin{array}{c}-0.009 * * * \\
(0.002)\end{array}$ & $\begin{array}{c}-0.011^{* * * *} \\
(0.003)\end{array}$ \\
\hline \multicolumn{11}{|l|}{ Smoking $>5$ Cigs. Daily } \\
\hline Minimum wage & $\begin{array}{l}-0.008 \\
(0.005)\end{array}$ & $\begin{array}{l}-0.009^{*} \\
(0.005)\end{array}$ & $\begin{array}{c}-0.010 * * \\
(0.005)\end{array}$ & $\begin{array}{l}-0.010^{* *} \\
(0.005)\end{array}$ & $\begin{array}{c}-0.010^{* *} \\
(0.005)\end{array}$ & $\begin{array}{c}-0.007 * * * \\
(0.003)\end{array}$ & $\begin{array}{c}-0.010 * * \\
(0.004)\end{array}$ & $\begin{array}{l}-0.007 \\
(0.004)\end{array}$ & $\begin{array}{c}-0.009 * * * \\
(0.003)\end{array}$ & $\begin{array}{c}-0.012 * * \\
(0.005)\end{array}$ \\
\hline Minimum wage (2012\$) & $\begin{array}{l}-0.007 \\
(0.004)\end{array}$ & $\begin{array}{l}-0.008^{*} \\
(0.004)\end{array}$ & $\begin{array}{c}-0.009 * * \\
(0.004)\end{array}$ & $\begin{array}{l}-0.008 * * \\
(0.004)\end{array}$ & $\begin{array}{c}-0.008^{* *} \\
(0.004)\end{array}$ & $\begin{array}{c}-0.005 * * \\
(0.002)\end{array}$ & $\begin{array}{c}-0.008 * * \\
(0.004)\end{array}$ & $\begin{array}{l}-0.006 \\
(0.004)\end{array}$ & $\begin{array}{c}-0.008 * * * \\
(0.002)\end{array}$ & $\begin{array}{c}-0.010^{* *} \\
(0.004)\end{array}$ \\
\hline $\begin{array}{l}\text { Includes time-varying } \\
\text { State controls }\end{array}$ & No & Yes & No & Yes & Yes & Yes & Yes & Yes & Yes & Yes \\
\hline
\end{tabular}

Notes: See Tables 3-5. Each cell represents a separate regression model. All models control for covariates listed in the notes to Table 3 